\title{
Freshwater mussels from South America: state of the art of Unionida, specially Rhipidodontini
}

\author{
Igor Christo Miyahira ${ }^{I^{*}}$, Sonia Barbosa dos Santos ${ }^{2}$ \& Maria Cristina Dreher Mansur ${ }^{3}$ \\ ${ }^{1}$ Universidade Federal do Estado do Rio de Janeiro, Avenida Pasteur, 458, 22290-240, Rio de Janeiro, RJ, Brazil \\ ${ }^{2}$ Universidade do Estado do Rio de Janeiro, Rua São Francisco Xavier, 524, 20550-900, Rio de Janeiro, RJ, Brazil \\ ${ }^{3}$ Universidade Federal do Rio Grande do Sul, Porto Alegre, RS, Brazil \\ *Corresponding author: Igor Christo Miyahira, e-mail: icmiyahira@yahoo.com.br
}

Miyahira, I. C.; Santos, S. B.; Mansur, M. C. D. Freshwater mussels from South America: state of the art of Unionida, specially Rhipidodontini. Biota Neotropica. 17(4): e20170341. http://dx.doi.org/10.1590/1676-0611-BN-2017-0341

\begin{abstract}
Unionida is the most diverse clade of freshwater bivalves. Among the groups occurring in South America, one with the highest number of species is Rhipidodontini (Hyriidae, Unionida, Paleoheterodonta, Bivalvia). However several issues remains on taxonomy and systematic of this group, leading to problems on species identification, description, as also as a limiting factor to other type of studies (e.g., ecology, conservation,...). In this paper is presented a synthesis of available knowledge about Diplodon Spix in Wagner, 1827 and Rhipidodonta Mörch, 1853 in South America, as a first step in order to a better understating of Rhipidodontini. The evaluation of different authors exposes the little agreement between them that resulted in a sort of divergent taxonomical opinions. Some comments on ecology, conservation and habitat preferences were made. This work can also encourage future research on taxonomy, systematic, ecology and conservation of freshwater mussels in South America.
\end{abstract}

Keywords: Diplodon, Rhipidodonta, Hyriidae, Bivalvia, Freshwater bivalve.

\section{Bivalves de água doce da América do Sul: estado da arte de Unionida, especialmente Rhipidodontini}

\begin{abstract}
Resumo: Unionida é o clado mais diverso de bivalves de água doce. Entre os grupos que ocorrem na América do Sul, um dos com maior número de espécies é Rhipidodontini (Hyriidae, Unionida, Paleoheterodonta, Bivalvia). Porém, diversas questões taxonômicas e sistemáticas ainda incidem sob este grupo, levando a problemas de identificação de espécies, descrição, entre outros, como também tem atuado como limitador de outros tipos de estudos (e.g., ecologia, conservação,..). Neste trabalho é apresentada uma revisão do conhecimento acerca dos gêneros Diplodon Spix in Wagner, 1827 e Rhipidodonta Mörch, 1853 na América do Sul como um primeiro passo para a melhor compreensão de Rhipidodontini. Avaliando-se diferentes autores, se torna claro a pouca concordância entre eles, resultando em opiniões taxonômicas divergentes. São feitos também alguns comentários sobre ecologia, conservação e preferências ambientais. Este trabalho também deve encorajar futuros trabalhos sobre a taxonomia, sistemática, ecologia e conservação de bivalves de água na América do Sul.
\end{abstract}

Palavras-chave: Diplodon, Rhipidodonta, Hyriidae, Bivalvia, Bivalve de água doce.

\section{Introduction}

Mollusca is the second phylum in number of species, with estimates on the number of living species ranging up to 200,000 (Ponder \& Lindberg 2008). Bivalvia constitutes one of the most representative groups of this phylum with more than 8,000 species living worldwide. Although most are marine species, about 1,300 live in freshwater in all continents, except Antarctica (Ruppert et al. 2005, Bogan 2008). Several lineages colonized freshwater ecosystems, especially the order Unionida (Paleoheterodonta), as well as some species of Arcida, Mytilida (Pteriomorpha), Venerida, Myida, and Anomalodesmata (Heterodonta), suggesting that bivalve invasions of freshwater environments occurred numerous times (Haag 2012). All living species of Unionida and
Sphaeriidae (Heterodonta: Venerida) live exclusively in freshwater (Mansur 2007, Giribet 2008). Freshwater mussels (Unionida) are one of the most endangered animal group due to continuous degradation of their ecosystems (Strayer et al. 2004, Amaral et al. 2008, Pereira et al. 2014). More recently Asian freshwater bivalves like Limnoperna fortunei (Dunker, 1857) (Mytilidae) and Corbicula spp. (Cyrenidae) that have been introduced to several distant countries and continents including South America caused severe ecological and economical loss (Darrigran \& Damborenea 2006, Mansur et al. 2012, Boltovskoy \& Correa 2015, Xu et al. 2015).

Bivalves inhabit the bottom substrate, and are important members of freshwater communities performing important ecosystem services (Vaughn 2017). Except for the environmental differences between marine 
and freshwater organisms, the freshwater species are generally similar to marine ones; although they are less colorful, camouflaged among sand grains and stones (Mansur 2007). Freshwater bivalves can be found in almost all available microhabitats, occupying different niches: burrowers of soft sediments (majority of species), burrowers of compacted sediments (e.g., Mycetopoda d'Orbigny, 1835 and Mycetopodella Marshall, 1928), wedgers of soft rocks and laterite (e.g., Bartlettia Adams, 1867), attached by byssus (e.g., Byssanodonta d'Orbigny, 1846 and Eupera Bourguignat, 1854) and species cemented to hard substrate (e.g., Acostaea d'Orbigny, 1851 and Etheria Lamarck, 1807) (Mansur 2007, 2012, Haag 2012, Pereira et al. 2014).

Our main goal was to summarize the knowledge about Unionida (Bivalvia, Paleoheterodonta) in South America, especially regarding Rhipidodontini (Hyriidae).

\section{Systematics of Unionida}

The taxonomic instability of bivalves results, in part, from the large amount of available names (Bieler \& Mikkelsen 2006), which change according to the different characters emphasized by each author. The systematic of Bivalvia was addressed by several authors (Thiele 1934, Newell 1965, Cox et al. 1969, Franc 1960, Schneider 2001, Giribet 2008) and the position of Paleoheterodonta remains quite stable. Paleoheterodonta is usually presented as a "halfway" between Pteriomorphia and Heterodonta (Schneider 2001, Giribet 2008). Bieler et al. (2014) presented a slightly different arrangement where Paleoheterodonta is sister group to Archiheterodonta, and this is sister to a clade composed by Anomalodesmata + Imparidentia, that embraces most bivalves previously in Heterodonta. Unionida is included in Paleoheterodonta and it is a group of usually large-sized mussels that have a peculiar life cycle with a parasitic stage and presents the most successful radiation in freshwaters by bivalves (Graf \& Cummings 2006, Haag 2012).

The inner relationships of Unionida are not as clear as the position of Paleoheterodonta. Simpson (1914) proposed only two families in Unionoida (= Unionida): Unionidae and Mutelidae. Most bivalves that are currently recognized as Unionidae, Margaritiferidae and Hyriidae (Figure 1A-C) compose the first group; and the current representatives of Mycetopodidae and Iridinidae are part of the second group (Figure 1D-E). Therefore, Unionidae sensu Simpson (1914) encompasses the species with larvae of glochidium type, whereas Mutelidae sensu Simpson (1914), those with the lasidium type. Ortmann (1921) recognized three families within the superfamily Naiades: Margaritanidae (= Margaritiferidae), Unionidae and Mutelidae (= Hyriidae + Mycetopodidae + Iridinidae). Based on morphological characteristics of their soft parts, not only on their shells, Ortmann $(1911,1921)$ noted similarities between hyriids and mutelids, and removed hyriids from Unionidae, establishing them as a subfamily of Mutelidae.

Thiele (1934) classified all freshwater mussels as Unionacea, recognizing four families: Margaritanidae, Unionidae, Mutelidae, and Aetheriidae (Figure 1). That is the first classification scheme that posed an exclusive family for freshwater oysters (Aetheriidae $=$ Etheriidae) (Figure 1F). Thiele (1934) used the same subfamilies of Mutelidae proposed by Ortmann (1921).

These first arrangements of Unionida follow biogeographical patterns: Boreal species grouped in Margaritiferidae (or Margaritanidae) and Unionidae; and Austral species in Mutelidae (= Hyriidae + Mycetopodidae) (Ortmann 1921, Thiele 1934). However, the separation is not clear cut, for example, Thiele (1934) left Virgus Simpson, 1900 and other austral insular species of Oceania in Unionidae.

Modell (1942) proposed four families (Mutelidae, Elliptionidae, Margaritiferidae, and Unionidae) with many subfamilies. Elliptionidae comprises the majority of species traditionally allocated in Unionidae. Modell (1942) also suggested a relationship between this group and Mutelidae, wherein all lasidium bearers were grouped together. Modell
(1942) as Simpson (1914), placed hyriids within Unionidae. According to Modell (1942), Mutelidae is a basal group that originates all other mussels. Parodiz \& Bonetto (1963) proposed an arrangement in two superfamilies based mainly on the larval type, which was widely accepted by subsequent authors: Unionacea (Unionidae + Margaritiferidae + Hyriidae) with glochidium larva; and Mutelacea (Mutelidae + Mycetopodidae) with lasidium larva. Etheriidae is not included in the classification, as its larval stage was unknown at that time (Bogan \& Roe 2008). The larval stage of Acostaea rivolii (Deshayes, 1827) (Etheriidae) was later identified as a lasidium (Arteaga-Sogamoso 1994, Bonetto, 1997). Kabat (1997) revised the names used in Unionida claiming that Etherioidea and Iridinidae should be used instead of Muteloidea and Mutelidae. The recent works accepted these suggestions (e.g., Graf \& Cummings 2007).

In the beginning of the $21^{\text {st }}$ century, there has been a reevaluation of systematic relationships based on phylogenetic methodologies, including molecular data in some of these analyses. The monophyly of Etheriidae was questioned by Bogan \& Hoeh (2000) who considered Acostea and Etheria (traditionally included in Etheriidae) within Mycetopodidae and, Pseudomulleria Anthony, 1907, an Indian freshwater oyster, inside Unionidae. Bogan \& Hoeh (2000) proposed multiple origins to cementation among freshwater bivalves, arguing the occurrence of the same process in the non-related Cyrenidae, Posostrea anomioides Bogan \& Bouchet, 1998. The analysis of Hoeh et al. (2001) is similar to Bogan \& Hoeh (2000), suggesting that Hyriidae is a sister group to the remaining Unionida and considering Unionacea (sensu Parodiz \& Bonetto, 1963) as a paraphyletic group. That scheme implies that the glochidium and the larvae incubation in the inner demibranch (endogenous) are plesiomorphic characteristics of Unionida.

Graf (2000) analyzed the relationships inside Etherioidea, with an emphasis on Hyriidae; suggesting that Hyriidae, Iridinidae and Etheriidae are monophyletic. Unionidae, once more had its monophyly questioned and Grandidieria Bourguignat, 1885, traditionally placed in Unionidae is considered a sister group of Etherioidea. Graf \& Cummins (2006) suggested that Paleoheterodonta is monophyletic and divided Unionoida in two clades: Unionoidea (Unionidae + Margaratiferidae) and Etherioidea (Hyriidae + Etheriidae + Mycetopodidae + Iridinidae). Unlike other authors (e.g., Bogan \& Hoeh, 2000; Hoeh et al. 2001), Graf \& Cummings (2006) suggested the monophyly of Unionidae and Etheriidae, condition latter also supported by Whelan et al. (2011). In that scheme, Unionoidea is the
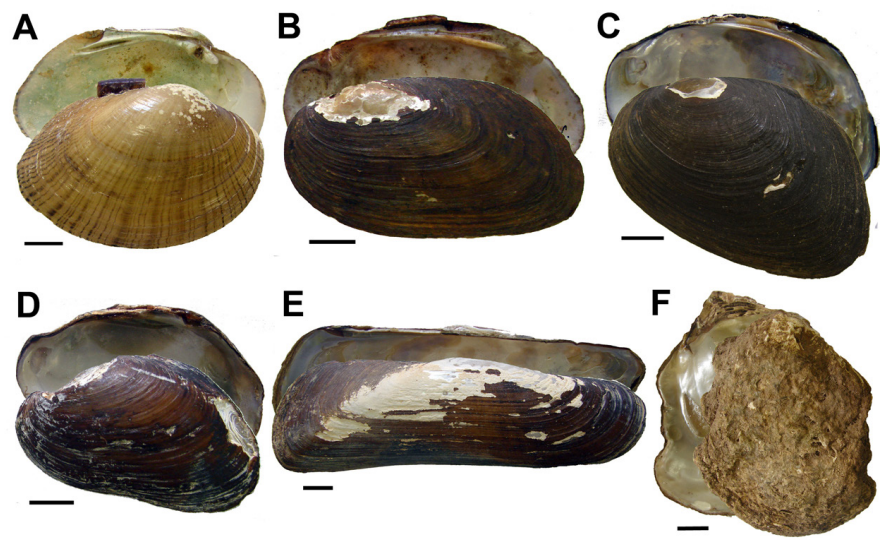

Figure 1. Members of Unionida. A - Unionidae, Lampsilis fasciola Rafinesque, 1820, MNRJ (Museu Nacional do Rio de Janeiro) 7468; B - Margaritiferidae, Margaritifera sp., MNRJ 32868; C - Echyridella menziesii (Dieffenbach, 1843), MNRJ 4374; D - Iridinidae, Aspatharia pfeifferiana (Bernardi, 1860), MNRJ HSL 6328; E - Mycetopodidae, Mycetopoda soleniformis d'Orbigny, 1835, MNRJ 3841; F - Etheriidae, Etheria elliptica Lamarck, 1807, MNRJ HSL 6111. Scale bar $=1 \mathrm{~cm}$. 
basal group of Unionida, while Hyriidae is the basal group of Etherioidea. In certain aspects, this arrangement is a return to early schemes of systematic organization (e.g., Ortmann, 1921) with boreal species separated from the austral species. The exceptions are some austral species of Unionidae (Haas 1969, Graf \& Cummings 2007).

Nevesskaja (2009) recognized two groups of living freshwater mussels: Unionoidea (Unionidae + Margaratiferidae) and Etherioidea (Mutelidae + Etheriidae), but did not list the genera within each group, so it is impossible to know precisely where Hyriidae and Mycetopodidae stand. As Mutelidae traditionally embrace the species of Iridinidae, Mycetopodidae and Hyriidae (Ortmann 1921, Thiele 1934, Graf 2000); we can suppose that Nevesskaja (2009) considered all the species of these families as belonging to Mutelidae.

A major point of disagreement between different authors is the position of Hyriidae, sometimes grouped with glochidium-bearing species, and sometimes grouped with the other Gondwanic species (Mycetopodidae and Etheriidae) (Bogan \& Hoeh 2000, Graf 2000, Graf \& Cummings 2006, Bogan 2008). Bieler et al. (2010) adopted an intermediate solution to the problem, dividing the living species of Unionida in three superfamilies (Table 1). In this classification, Hyrioidea (represented only by Hyriidae) occupy an intermediate position between the two other groups, Etherioidea and Unionoidea, reflecting the conflicting data from other authors concerning the position of Hyriidae (Bogan \& Hoeh 2000, Hoeh et al. 2001, Graf \& Cummins 2006, 2007). Graf et al. (2015) presented Hyriidae as sister to all other freshwater mussel families, in a position quite different from the previously one (Graf \& Cummings 2006), however similar (regarding to Hyriidae position) to topology presented by Bogan \& Hoeh (2000) and Hoeh et al. (2009).

\section{Geographical distribution of South American mussels}

Unionida occurs worldwide in different kinds of freshwater habitats except in Antarctica (Graf \& Cummings 2006, Bogan 2008). Current estimates recognize approximately 900 species distributed among six families: Hyriidae, Mycetopodidae, Unionidae, Iridinidae and Etheriidae (Graf \& Cummings 2006, 2007, Bieler et al. 2010).

Etheriidae is Gondwanic and comprises four species, occurring in Africa, Etheria elliptica Lamarck, 1807; India, Pseudomulleria dalyi (Smith, 1898) and South America, Acostea rivolii and Bartlettia stefanensis (Moricand, 1856) (Haas 1969, Graf \& Cummings 2006, 2007). The monophyly of this family is disputed and there is no agreement as highlighted by different opinions available (Parodiz \& Bonetto 1963, Bogan \& Hoeh 2000, Bonetto 1997, Simone 2006, Hoeh et al 2009, Mansur et al. 2012).

Mycetopodidae is Neotropical distributed all over South America east of the Andes and west of Central America all the way to Mexico (Graf \& Cummings 2006, Bogan 2008). There are about 30 valid species of Mycetopodidae in 12 (Simone 2006) or 11 genera (Graf \& Cummings 2007). Bonetto (1997) also includes Acostaea in Mycetopodidae, whereas other authors (Parodiz \& Bonetto 1963, Graf 2000) believe that Leila Gray, 1840 , usually placed in Mycetopodidae, belongs to Iridinidae. The origin of Mycetopodidae is in the Cretaceous (Cox et al. 1969).

There are around 80 species of Hyriidae, occurring throughout Oceania and South America, with only two or three species west of the Andes (Bonetto et al. 1986; Parada \& Peredo, 2002; Graf \& Cummings, 2007; Bogan, 2008). Hyriidae is monophyletic (Graf et al. 2015) and usually divided in two groups (sub-families), the Hyriinae, which comprises South American species, except by Hyridella Swainson, 1840 and some related Australian species; and Velesunioninae, that comprises most Australian species (Graf \& Cummings, 2006, 2007; Bieler et al. 2010; Graf et al. 2015). Among Hyriidae seven genera are recognized to South America: Prisodon
Schumacher, 1817; Paxyodon Schumacher, 1817; Callonaia Simpson, 1900; Castalia Lamarck, 1819; Castaliella Simpson, 1900; Diplodon Spix in Wagner, 1827 and Rhipidodonta Mörch, 1893 (Simone, 2006); and, nine genera to Australia: Hyridella; Cucumerunio Iredale, 1934; Echyridella McMichael \& Hiscock, 1958; Virgus; Velesunio Iredale, 1934; Alathyria Iredale, 1934; Lortilella Iredale, 1934; Microdontia Tapparone Canefri, 1883; Westralunio Iredale, 1934 (Graf \& Cummings, 2007). It is noteworthy that not all authors agree with the valid status of each of these genera. Simone (2006) considered Triplodon Spix in Wagner, 1827 as synonym, unlike Mansur \& Pimpão (2008) who described a new species of this genus. The oldest Hyriidae record is from Triassic of New Zealand (Campbell et al. 2003) and from Jurassic of South America (Perea et al. 2009). Molecular clock indicated a Gondwanan origin of Hyriidae (Graf et al. 2015; Santos-Neto et al. 2016).

The Figures 2 to 4, based on the data available in Graf \& Cummings (2007), allow a more detailed evaluation of the distribution of the South American species of Hyriidae, Etheriidae and Mycetopodidae. Graf \& Cummings (2007) divides the Neotropical region in six areas: Mesoamerica (including Cuba), Transandean (including the basins of rivers Magdalena and Maracaibo), Amazonas-Orinoco (including the Guyanas), Atlantic coastal streams (including the São Francisco River basin), Paraná-Paraguay and Patagonia. The two main families (Hyriidae and Mycetopodidae) are widespread in the region; Mycetopodidae occurs in all regions and Hyriidae in five of them (Figure 2). Etheriidae are limited to three regions. In the regions of Atlantic coastal streams, Paraná-Paraguay and Patagonia prevails species of Hyriidae; in the others regions, there are

Table 1. Relationships of Paleoheterodonta, following Bieler et al. (2010), modified to include only the living taxa of Paleoheterodonta.

\begin{tabular}{lccc}
\hline Paleoheterodonta & Trigoniida & Trigonioidea & Trigoniidae \\
& Unionida & Etherioidea & Etheriidae \\
& & Iridinidae \\
& & Mycetopodidae \\
& Hyrioidea & Hyriidae \\
& Unionoidea & Unionidae \\
& & Margaritiferidae \\
\hline
\end{tabular}

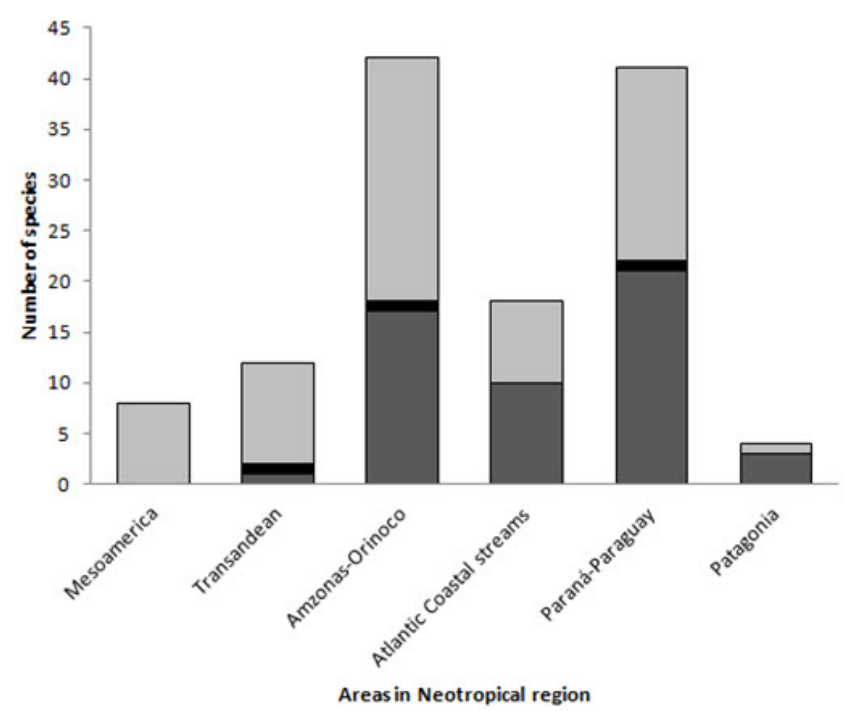

Figure 2. Number of species of Hyriidae and Mycetopodidae in different areas of Neotropical region. Based on the original data by Graf \& Cummings (2007). Key: Dark gray - Hyriidae; Black - Etheriidae and Light gray - Mycetopodidae. 


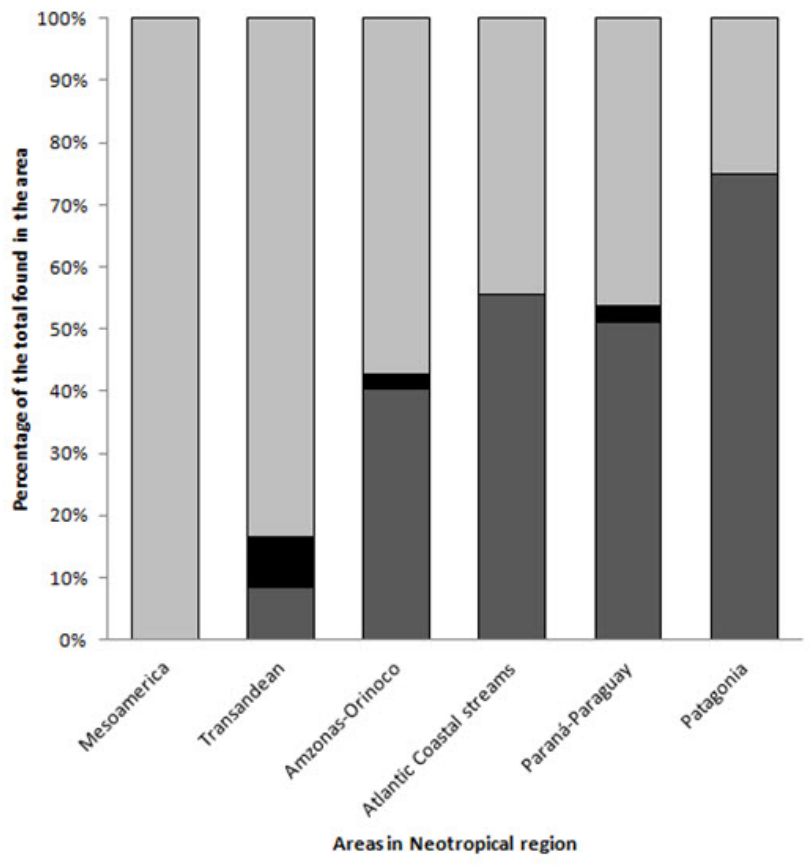

Figure 3. Representativeness of Hyriidae, Mycetopodidae and Etheriidae in the Neotropical region based on the original data by Graf \& Cummings (2007). Key: Dark gray - Hyriidae; Black - Etheriidae and Light gray - Mycetopodidae.

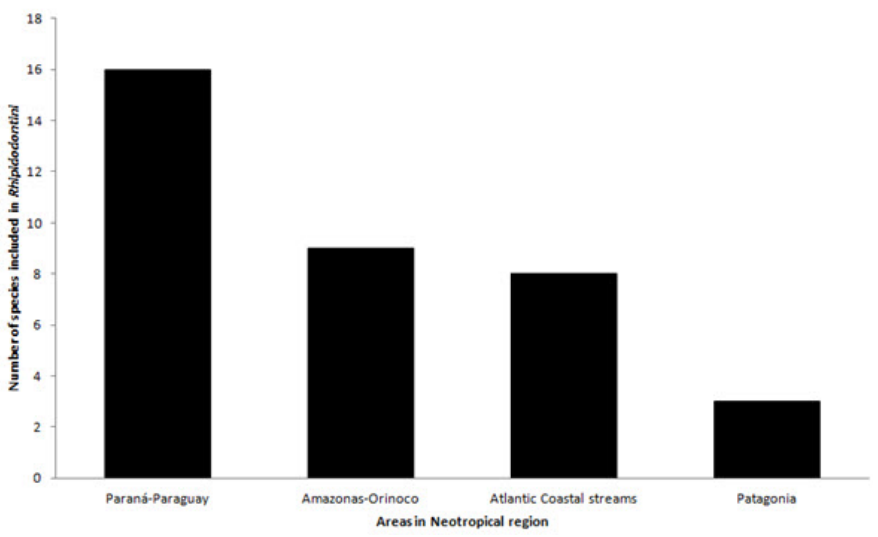

Figure 4. Number of species of Rhipidodontini (Rhipidodonta + Diplodon) in Neotropical region. The regions that are not presented don't have any Rhipidodontini species (i.e. Mesoamerica and Transandean). Based on the original data by Graf \& Cummings (2007)

more Mycetopodidae species (Figure 2). The areas with the greatest total number of species are Amazonas-Orinoco (42 spp.) and Paraná-Paraguay (41 spp.), the first with the greatest number of Mycetopodidae (24 spp.) and the second with the greatest number of Hyriidae (21 spp.). Pereira et al. (2014) indicated the same areas as those of high diversity and pointed all region east of Andes (except by Northeast Brazil) as phylogenetically structured by Hyriidae and Mycetopodidae.

Comparing the representativeness of each family in different areas, we notice a trend towards a decrease in Mycetopodidae, along with an increase in Hyriidae (Figure 3), from North to South. The extremes are Mesoamerica, without Hyriidae species, and Patagonia where Hyriidae represents more than $70 \%$ of Unionida fauna. However, Patagonia is a poor region in mussels richness and this high percentage amounts to only three species. Etheriidae is always a small fraction of total species.

Figure 4 presents the diversity of Rhipidodontini (Rhipidodonta + Diplodon). There are no representatives of Rhipidodontini in the Mesoamerica and Transandean regions. The unique species of Hyriidae pointed out by Graf \& Cummings (2007) to Transandean region is Castalia multisulcata Hupé, 1857 that belongs to Castaliini. Rhipidodontini represents most species of Hyriidae in Neotropics resulting in similarities between figure 4 and 2. The difference between the Amazonas-Orinoco region and Atlantic coastal streams region, lower in Figure 2 than in Figure 4, are due to the occurrence of exclusive Amazonian Hyriidae genera like Callonaia, Castaliella and Prisodon. Graf \& Cummings (2007) included these genera in other tribes (Hyriini or Castaliini).

\section{Taxonomy and systematics of Rhipidodontini}

The most important studies concerning the systematics of Rhipidodontini (Figure 5) are shown in Table 2 and Appendix I (see Supplementary material): Simpson (1914), Ortmann (1921), Morretes (1949), Parodiz (1968), Haas (1969), Simone (2006) and Graf \& Cummings (2007). The following discussion focused on specific epithet, regardless of the genus or subgenus the author employed. For example, Haas (1969) used Diplodon (Rhipidodonta) rhombea Spix in Wagner, 1827, while Graf \& Cummings (2007) used Rhipidodonta rhombea; regardless of genus designation, we regarded that both authors considered "rhombeus" as a valid species. Diplodon is traditionally divided in subgenera, mainly based on features of the shell, and the two most used are Rhipidodonta and Diplodon s.s.

Simpson (1914) and Thiele (1934) recognized three subgenera: Diplodon s.s., Rhipidodonta (= Cyclomya Simpson, 1900) and Bulloideus Simpson, 1900 (see Table 2 and Appendix I). Ortmann (1921) and Morretes (1949) recognized two subgenera, Diplodon and Rhipidodonta. The species placed in Bulloideus were usually included in Rhipidodonta by the authors that did not use the first subgenera. Haas (1969) recognized four subgenera, adding Schleschiella Modell, 1950 to those mentioned previously. Ortmann (1921) was the first to notice differences in glochidium, however, he did not assign those variations to subgenera. The characteristics of glochidium were linked to subgenera by Bonetto $(1961,1965)$ and Parodiz \& Bonetto (1963). Simone (2006) raised Rhipidodonta to genus status, an idea followed later by Graf \& Cummings $(2006,2007)$, considering Diplodon to encompass the species with parasite glochidium, and Rhipidodonta those with non-parasite glochidium. These two genera (Diplodon and Rhipidodonta) were included in tribe Rhipidodontini (Graf \& Cummings 2007), with all species previously arranged in subgenera by other authors (Table 2, Appendix I). Simone (2006) do not presented an explanation to support his decision, and probably for this reason some authors like Pereira et al (2014) don't followed his suggestions. It is clear that glochidium is a good diagnostic feature in Hyriidae (Parodiz \& Boneto 1963, Mansur 1999, Mansur \& Silva 1999, Pimpão et al. 2012), but is also necessary to find other characteristics on the morphology of adult specimens as well as on molecular aspects to substantiate this division. It is also important to mention that in South America there are many under-sampled areas and undescribed glochidia of Rhipidodontini. We propose to adopted parsimoniously the suggestion of Simone (2006), using Rhipidodonta only to the species that the glochidium is described and without any doubts about identification.

Glochidium is known for 31 nominal species of Diplodon and for 17 nominal species of Rhipidodonta. In cases where the glochidium type is missing, the genus assignment is based only on adult shell morphology. That is the case of some species recognized in several works as Diplodon rhombeus (= Rhipidodonta rhombea after Simone 2006) (Figure 5G). There were also some cases of "change" of the glochidium type, after detailed revision; for example, glochidium type in Diplodon suavidicus (d'Orbigny, 1835) (Figure 5E) was firstly assigned as non-parasite (Simone 2006) and 

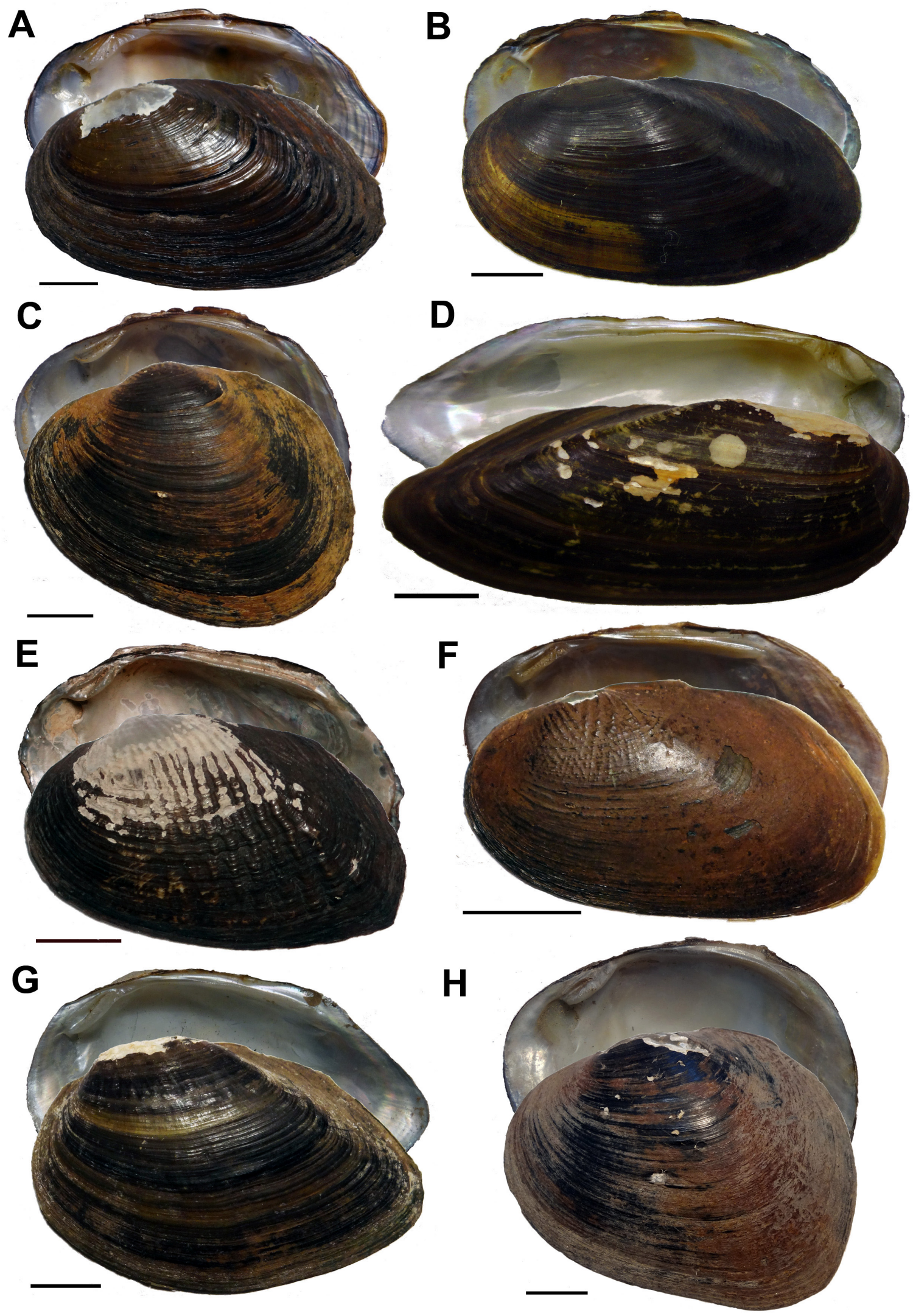

Figure 5. Members of Rhipidodontini. A- Rhipidodonta charruana (d'Orbigny, 1835), MHNM (Museo Nacional de Historia Natural - Montivideo) 1210; B - Diplodon chilensis (Gray, 1828), LMD (Aquazoo Löbbecke Museum Düsseldorf) w/n (Lisikhe collection); C - Diplodon fontainianus (d'Orbigny, 1835), MHNM 6285; D - Diplodon parallelopipedon (Lea, 1834), LMD w/n (Lisikhe collection); E - Rhipidodonta hylaea (d'Orbigny, 1835), ZMB (Museum für Naturkunde) w/n (Paetel collection); F - Diplodon multistriatus (Lea, 1831), MHNM 3966; G - Diplodon parodizi Bonetto, 1962, MHNM - Soc. Taguató 670; H - Diplodon rhombeus Spix in Wagner, 1827, SMF (Senckenberg Forschungsinstitut und Naturmuseum)11248. Scale bar $=1 \mathrm{~cm}$. 
later as parasite (Pimpão et al. 2012). Pimpão et al. (2012) successfully used the glochidium to differentiate Amazonian species of Hyriidae, thus proving that glochidium can be powerful in species delimitation.

One concept that appeared in several older works was that of a "group of species" (Simpson 1914, Ortmann 1921, Haas 1930, 1931a,b), abandoned in more recent works (Haas 1969, Simone 2006, Graf \& Cummings 2007). A "group of species" includes several species that share some characteristics, usually the shell structure, and the most prominent species (according to the author) lend their name to the group. However, the characteristics of the different groups are not very clear, which led to some overlapping. A group of species does not hold taxonomic status and is used only as a way to organize the species by morphological similarity. All the authors that used "group of species" presented six groups; however, the choice of main species and the composition of each group was different (Table 3). The groups of Diplodon granosus (Bruguière, 1792) and D. delodontus (Lamarck, 1819) $(=$ D. lacteolus) were mentioned by the three authors above (Simpson 1914, Ortmann 1921, Haas 1930, 1931a,b); however, the species included in each group were different according to each author. For example, Simpson (1914) allocated 27 species in the group of D. granosus, whereas Ortmann (1921) and Haas (1930, 1931a,b), proposed only one species with three subspecies. The concept of "group of species" was similar to the concept of "super-species" used by Parodiz (1968, 1973), but also not applied in subsequent works (e.g., Simone 2006, Graf \& Cummings 2006).

Simpson (1914) presented the highest number of species (80), with seven new species and one new subspecies. Some species names were used only by Simpson (1914) like Diplodon ampullaceus (Lea, 1866), Diplodon aplatus (Reeve, 1865), Diplodon effulgens (Lea, 1856), Diplodon modestus (Küster, 1856), Diplodon quadrans (Lea, 1859) and Diplodon rufofuscus (Lea, 1859). Simpson (1914) also included some Australian species in Diplodon (subgenera: Hyridella, Cucumaria and Laevirostris), which were removed by subsequent authors (e.g., Ortmann 1921, Haas 1969). Simpson (1914) synonymized some species names and described the species based mainly on their shell, using few information about the soft parts. Diplodon dunkerianus (Lea, 1856) and D. martensi (Ihering, 1893) were only presented by Simpson (1914) and Parodiz (1968), among the authors of Table 2. However, there are more recent references to D. martensi (Mansur 1970, Vaz et al. 1987, Mansur 1999, Pfeifer \& Pitoni 2003) and D. dunkerianus (Amaral et al. 2008).

Ortmann (1921) presented a similar number of species compared to later works (Haas 1969, Graf \& Cummings 2007); however, the species listed were different. Ortmann based on the Unionida soft-parts morphology, proposed the first phylogenetic relationships of the Unionida families and subfamilies, as well as one of the first schemes to classify the South American naiades, which is still partially accepted. He also brought a wealth of information on the shell comparative morphology and glochidia of Hyriidae, a tool needed to better understand the high degree of polymorphism at the specific level.

The tendency to describe several new species decreases after Ortmann (1921). However, Haas $(1916,1929,1938,1966)$ still described four new species in separate works. This change in point of view is probably due to a better comprehension of shell polymorphism. The study of the naiads starts to acquire its current shape in Haas (1969), when he upgraded and expanded the synonymic lists started by Simpson (1914) and Ortmann (1921). Several species validated by Haas (1969) remained with the same status in subsequent works. For example, out of the 27 species considered valid by Graf \& Cummings (2007), 23 received the status of species or subspecies by Haas (1969).

There are 149 species names associated to Diplodon and Rhipidodonta, excluding fossil species and nomen nudum (Parodiz 1968, Bonetto \& Tassara 1987), $109(73.15 \%)$ were used in species or subspecies rank by at least one of the authors of Table 2 and Appendix I (Simpson 1914, Ortmann 1921, Morretes 1949, Parodiz 1968, Haas 1969, Simone 2006, Graf \& Cummings 2007), leaving out 40 species names $(26.85 \%)$ that were not used by any of them. Despite the high number of species names used (i.e. 109), most of them were used only by one or two authors, $28.86 \%$ and $18.80 \%$, respectively (Figure 6, Appendix I).

Table 2. Number of species of Rhipidodontini considered valid by different authors. Noteworthy that for our purposes, a global scope work is almost equal to a South America scope because the recent fauna Rhipidodontini occurs only in South America. * - The author presents some Australian forms as Diplodon subgenera (Hyridella Swainson, 1840; Cucumaria Conrad, 1853; Laevirostris Simpson, 1900), that are not included in this table, in order to allow an equal comparison with other authors ** - Considered doubtful by the author.

\begin{tabular}{|c|c|c|c|}
\hline Reference & Genera or subgenera & Number of valid species & Geographic scope \\
\hline Simpson (1914) & $\begin{array}{c}\text { Diplodon (Diplodon); Diplodon } \\
\text { (Cyclomya); Diplodon (Bulloideus) }\end{array}$ & 80 species +4 subspecies* & Global \\
\hline Ortmann (1921) & $\begin{array}{c}\text { Diplodon (Diplodon); Diplodon } \\
\text { (Cyclomya) }\end{array}$ & 28 species & South America \\
\hline Morretes (1949) & $\begin{array}{c}\text { Diplodon (Diplodon); Diplodon } \\
\text { (Rhipidodonta) }\end{array}$ & 36 species +2 subspecies & Brazil \\
\hline Haas (1969) & $\begin{array}{c}\text { Diplodon (Diplodon); Diplodon } \\
\text { (Rhipidodonta); Diplodon } \\
\text { (Schleschiella); Diplodon (Bulloideus) }\end{array}$ & 22 species +13 subspecies & Global \\
\hline Parodiz (1968) & $\begin{array}{c}\text { Diplodon (Diplodon); Diplodon } \\
\text { (Rhipidodonta) }\end{array}$ & 32 species +6 subspecies & South America \\
\hline Simone (2006) & Diplodon; Rhipidodonta & $\begin{array}{l}22 \text { (14 spp. in Diplodon, } 8 \text { spp. in } \\
\text { Rhipidodonta })+2 \text { spp. doubtful }{ }^{* *}\end{array}$ & Brazil and nearby areas \\
\hline Graf \& Cummings (2007) & Rhipidodonta; Diplodon & $\begin{array}{c}27 \text { (19 spp. in Diplodon, } 8 \text { spp. in } \\
\text { Rhipidodonta) }\end{array}$ & Global \\
\hline
\end{tabular}

Table 3. Groups of species of Diplodon Spix in Wagner, 1827 presented by different authors.

\begin{tabular}{cc}
\hline Author & Groups proposed \\
\hline Simpson $(1914)$ & Diplodon lacteolus, D. granosus, D. burroughianus, D. pazi, D. parallelipipedon, D. quadrans \\
Ortmann $(1921)$ & D. hylaeus, D. granosus, D. chilensis, D. charruanus, D. lacteolus, D. ellipticus \\
Haas $(1930,1931 \mathrm{a}, \mathrm{b})$ & D. chilensis, D. charruanus, D. hylaeus, D. parallelipipedon, D. delodontus, D. granosus \\
\hline
\end{tabular}


Only four species $(2.68 \%)$ are recognized as valid by all authors, namely: Diplodon charruanus (d'Orbigny, 1835), Diplodon granosus, Diplodon hylaeus and Diplodon parallelopipedon (Lea, 1834) (Figure 5A,D,E). Besides these, all the authors cited the "set" ellipticus Spix in Wagner, 1827 + wagnerianus Simpson, 1900 that refers to the same biological species, though Haas (1969) used ellipticus as a subspecies of Diplodon granosus. This agreement between the authors could suggest that these species are easily recognizable. This is (probably) true to Diplodon hylaeus and Diplodon parallelopipedon, which have peculiar shell characteristics. The others (charruanus/granosus/ellipticus) were among the first species described to South America and have priority but were involved in taxonomical problems.

Six names: D. besckeanus (Dunker, 1848), D. burroughianus (Lea, 1834), D. suavidicus (Lea, 1856), Diplodon gratus (Lea, 1860), Diplodon patagonicus (d'Orbigny, 1835) and Diplodon fontainianus (d'Orbigny, 1835) were used by six authors as species or subspecies, representing $4.03 \%$ of all names. Diplodon lacteolus is clearly a synonymy of Diplodon delodontus as already noted by Lea (1836) in the original description. The "set" lacteolus + delodontus was mentioned by all the authors except for Morretes (1949).

This evaluation illustrates the divergence among authors, a result of different characteristics employed for species differentiation. Even in the species recognized by most authors, there are considerable differences in descriptions and synonymic lists.

Despite the differences in the geographic scope of Simone (2006) and Graf \& Cummings (2007), they agree completely about the eight species included in Rhipidodonta. The few differences between these authors comprised species included in Diplodon s.s. Five species in Graf \& Cummings

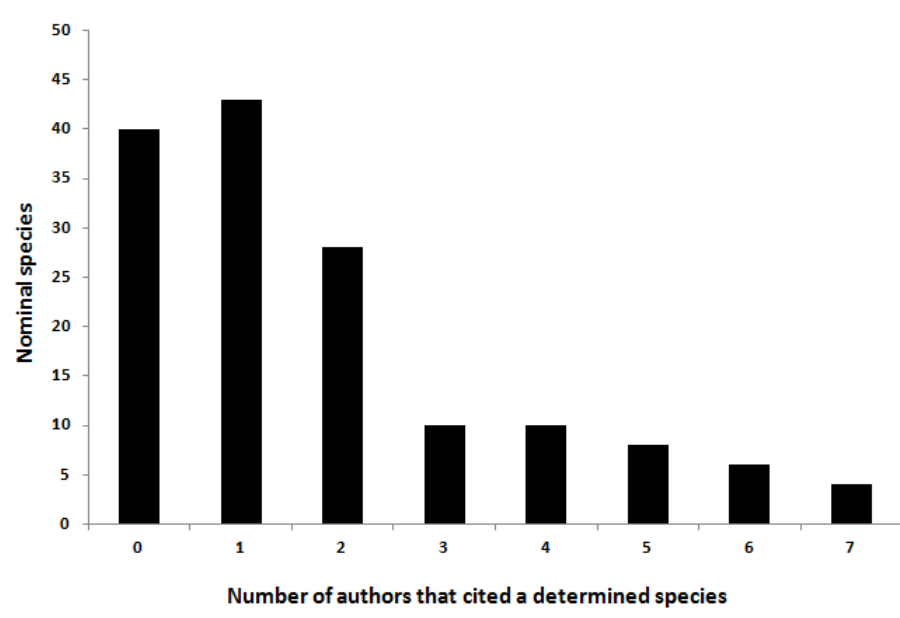

Figure 6. Number of times that a determined nominal species is cited by the evaluated authors (Table 3). See the Appendix I to base data.
(2007) were not included in Simone (2006), namely: Diplodon chilensis (Gray, 1828); Diplodon flucki Morrison, 1943; Diplodon guaporensis Bonetto \& Tassara, 1987; Diplodon losadae Haas, 1966 and Diplodon solidulus (Philippi, 1869). Despite the differences, Simone (2006) and Graf \& Cummings (2007) were the most similar works presented in Appendix I.

\section{Identification of Rhipidodontini}

Shell characteristics were considered since the first researches on Rhipidodontini (e.g., Simpson 1914). The study of anatomical features was introduced by Ortmann (1921) and recently some molecular studies were done (e.g., Graf \& Cummings 2006, Santos-Neto 2016). However, none of these approaches have been exhausted.

The shell outline was used for a long time to differentiate the subgenera of Diplodon. For example, the rounded species were asserted to Rhipidodonta and the more elongated species to Diplodon s.s. This division based only on shell proven to be artificial and not agree with other aspects. Nowadays, the shell structures were still in use and were not described in detail for most species (Miyahira et al. 2013). The most important characteristics of the shell are the umbo position, umbonal sculpture and hinge details. The ultra-structure of the shell was poorly studied in Hyriidae (Bieler et al. 2014) and must to be improved.

Only after the studies of Ortmann (1921) and Parodiz \& Bonetto (1963) that provide the basic information on the glochidium type (with or without hooks) it was possible to link larva to subgenera and later to genera. Diplodon has glochidium with hooks and an obligate stage as parasite of fishes (Mansur et al. 2012, Pimpão et al. 2012). The life cycle of D. martensi was described by Mansur (1999) and remains as the unique species to have the cycle described in Brazil. The glochidium of Rhipidodonta is hookless and the life cycle still poorly known. The glochidium develop at the marsupium and the mussel release a juvenile (Wächtler et al. 2001, Mansur \& Silva 1999, Mansur et al. 2012, Pimpão et al. 2012). Unfortunately the glochidium type was not described to all species of Rhipidodontini (Table 4). According to Pimpão et al. (2012) the glochidium was useful not only to separate the genera but also to identify species based on morphometrics and a detailed description. In order to avoid unnecessary taxonomical fluctuations, it is recommended that species remains at Diplodon until information on glochidia were obtained.

Some details of internal morphology was described only to the following species, Diplodon charruanus, D. pilsbry Marshall, 1928, D. besckeanus, D. multistriatus (Lea, 1831), D. rhombeus fontainianus and D. rotundus gratus (Hebling \& Penteado 1974, Alvarenga \& Ricci 1981, Mansur \& Anflor 1982, Ricci et at 1988, Avelar \& Cunha 2009). Meyer et al. (2012, 2014) described the reproductive system of $D$. expansus (Küster, 1856) and D. ellipticus from a histological perspective. Considering the reduced knowledge about Rhipidodontini morphology it is difficult to elect good diagnostic features in soft parts. Until now some differences between species were found with success on the outline and morphology of branchiae, position of marsupium, labial palps and stomach.

Table 4. Nominal species of Rhipidodontini with glochidium type described in the literature. (Lea 1869, Ortmann 1921, Bonetto 1954, 1960, 1961, Bonetto \& Ezcurrade-Drago 1965, Alvarenga \& Ricci 1979, Bonetto et al. 1986, Mansur \& Campos-Velho 1990, Ricci et. al. 1990, Martinez-Escabassiere \& Royero 1995, Mansur \& Silva 1999, Pimpão et al. 2012). We used Diplodon for all species to avoid new combinations without further studies

Glochidium with hooks (Diplodon s.s.)

D. atratus, D. berthae, D. besckeanus, D. decipiens, D. delodontus,

D. ellipticus var. santanus, D. expansus, D. granosus, D. guaranianus,

D. firmus, D. fontaineanus, D. frenzeli, D. hartwrighti, D. imitator, D. martensi,

D. mogymirim, D. multistriatus, D. obsolescens, D. parallelopipedon,

D. parodizi, D. paulista, D. peculiares, D. piceus, D. rhuacoicus, D. rotundus,

D. simillimus, D. solidulus, $D$. suavidicus, $D$. trivialis, $D$. vicarius,

D. wagnerianus e D. yaguaronis
Hookless glochidium (Rhipidodonta)

$D$. assuncionis, D. bulloides, D. burroughianus, D. charruanus, D. garbei,

$D$. hasemani, D. hildae, D. hylaeus, D. iheringi, D. koseritzi, D. paranensis,

D. peraeformis, D. rhuacoicus, D. subcuadratus, D. suppositus e D. variabilis 
Only four species of Diplodon were used in molecular approaches: D. deceptus Simpson, 1914, D. suavidicus, D. demeraraensis (Lea, 1859) and D. chilensis (Hoeh \& Bogan 2000, Graf et al. 2015, Santos-Neto et al. 2016). All these molecular studies deals with wider questions, inner relations of Rhipidodontini were never investigated in detail.

Analyzing all these information, it is clear that several gaps remain in available knowledge about Rhipidodontini. More data are necessary to provide better species identification and consequently the genera differentiation. Nowadays, the unique secure attribute to separate Diplodon and Rhipidodonta is the glochidium type. All these data will be necessary to discover the internal relationships of Rhipidodontini.

\section{Ecological preferences of Rhipidodontini}

The species can occur in lentic or lotic habitats, from small streams to big rivers and lakes; however, they are not common in strong currents They tolerate a wide granulometric range, but prefer fine sediments, usually rich in organic matter. Some species can occur between or below pebbles, or even in rock cracks. They usually start appearing at a depth of $30 \mathrm{~cm}$. They are sometimes found associated to roots of aquatic plants (Avelar \& Cunha 2009). They prefer the final sections of the river, due to the highest amount of nutrients, and are rare or absent in headwaters (Pereira et al. 2011, Miyahira et al. 2017). They can share space with other native freshwater mussels, as is commonly seen in southern Brazil, northern Argentina and Uruguay, apparently without harm to the species (Mansur \& Pereira 2006, Pereira et al. 2011, 2014, Mansur et al. 2012). The species of Rhipidodontini are sensitive to environmental changes and suffer with domestic and industrial sewage discharge, the main cause of decrease in populations of freshwater mussels (Strayer et al. 2004; Miyahira et al. 2012; Mansur et al. 2012; Pereira et al. 2014).

\section{Threats and the conservation of Unionida}

Freshwater mussels are among the most endangered species (Strayer et al. 2004, Bogan 2008, Santos et al. 2009, Miyahira et al. 2012). The main cause of this threat is the habitat change. At the basin of the Paraná River, one of the richest areas in Brazil regarding freshwater mussels, there is a series of 70 reservoirs, turning a long-term survival difficult for mussels (Santos et al. 2009, Mansur et al. 2012, Pereira et al. 2014). The change of lotic to lentic habitats caused by the dams profoundly changes the physical and chemical conditions, affecting not only the mussels but also the host fishes (in the case of parasitic life cycle of Diplodon). This situation creates relictual populations of mussels, alive but fated to die, because they cannot reproduce or disperse without fish host. The long life achieved by these mussels allows them to have a long survival, but without any hope (Philipp \& Abele, 2009). This situation created an extinction debt that already stated to be paid in North American fauna with several recent extinctions (Haag 2012).

Freshwater mussels were exploited by the mother of pearl button industry for a long time, mainly in North America (Neves 1999, Haag 2012), but also in South America (Beasley 2001, Matos 2007, Clavijo 2017). That exploitation caused the decline of several mussel populations in the USA, especially in the first half of the twenty century (Strayer et al. 2004, Haag 2012). Although usually considered a threat from the olden days, populations of Paxyodon, Triplodon and Castalia in the Brazilian Amazon are still exploited by the button industry (Beasley 2001, Matos 2007).

Recently, one of the major threats to the native bivalves is the introduction of invasive species (Haag 2012, Mansur et al. 2012). Among the most harmful species that were introduced to Brazil are Limnoperna fortunei, Corbicula fluminea (Müller, 1774), Corbicula fluminalis (Müller, 1774) and Corbicula largillierti (Philippi, 1844). Limnoperna fortunei (golden mussel) has caused the worst damages to native mussels populations, as they grow over any hard substrate, including the shell of native mussels, preventing them to open their valves, causing death by suffocation and starvation (Mansur et al. 2004a, Darrigran \& Damborenea 2006, Mansur et al. 2012). Besides the ecological problems, the introduced species can cause several economic losses to industries and energy plants; clogging pipes, filters and other structures (Mansur et al. 2004a,b, Darrigran \& Damborenea 2006, Mansur 2007, Darrigran et al. 2007). The damages caused by these bivalves were recently reviewed by Boltovskoy \& Correa (2015).

In the 2008 edition of the Brazilian Red Book of Threatened Species, 26 out of the 29 listed molluscs are freshwater mussels, including ten species of Diplodon (Amaral et al. 2008). However, a recent re-evaluation of the list (Santos et al. 2015), which strictly used the criteria of IUCN listed only two species as threatened, 11 as Data Deficient and 9 as Near Threatened. It is clear that the environmental conditions in Brazil not improved in these few years. This is actually an evidence of the lack of data and the risk of extinction must be re-evaluated considering the Brazilian reality. The threat to freshwater mussels is a global phenomenon. In North America, there are 73 species critically endangered and 37 probably extinct (Neves 1999, Strayer et al. 2004, Haag 2012).

Knowledge on freshwater mussels of Brazil is not sufficient, with several important data to species extinction evaluation risk missing, such as information about population dynamics and reproductive cycle. This prevents the inclusion of species in IUCN risk categories, unless if distribution evidence is used, the better data that we have. However, even the information about distribution has problems. Many times the distribution of freshwater mussels is assigned to a hydrographic basin as a whole (e.g., Simone 2006, Mansur et al. 2012); however, the situation in the "real world" is quite different, as the distribution of the species is not homogeneous and depends on several environmental factors (Haag 2012, Mansur et al. 2012). The mussels assemblages are patchily distributed and the movements in adult mussels are restricted (Pereira et al 2011, Haag 2012, Vaughn 2017, Miyahira et al. 2017). Thus, the distribution of a mussel can never consider the basin as the whole for evaluation of extinction risks. Pereira et al. 2011 evaluated six sites along a gradient at a stream in the state of Rio Grande do Sul (Brazil); Anodontites trapesialis (Lamarck, 1819) and Anodontites lucidus (d'Orbigny, 1835) were found in one site; $A$. patagonicus (Lamarck, 1919) in two; and Diplodon pilsbry in three. Similar situation is found by Miyahira et al. (2017) in a river at state of Rio de Janeiro (Brazil); A. trapesialis and D. ellipticus where found respectively in two and three sites out of ten surveyed. Another problem about distribution information is the use of old data obtained in literature and museums records (e.g., Mansur \& Pereira 2006, Simone 2006, Miyahira et al. 2013). Thus, the distribution presented in most works is closest to the original, but also includes several places where species do not occur anymore, leading to a wrong evaluation of the risk of extinction.

Moreover, complete morphological information is absent as detailed above and this not affect only the taxonomy, but also conservation. For example, Diplodon pfeifferi (Dunker, 1848) is a species recorded only at the state of Rio de Janeiro and listed in 2008 edition of the Brazilian Red Book (Amaral et al. 2008) but some authors include this species in the synonym of D. granosus (Simpson 1914, Haas 1969, Simone 2006), a species not listed as threatened. It is clear that the correct identification of these two species is not only a problem of taxonomy.

It is necessary to improve the evaluation of risk to our mussels, some recommendations are done: 1) detail the distribution of the species relating, when possible, to environmental factors; 2 ) separate the old (or museum) records from current records; 3) collect in sub-sampled areas; 4) improve our knowledge on morphology and genetics to solve the taxonomical questions; 5) study the population dynamics of the species and 6) study the species reproduction cycle. 


\section{Summary of studies on Brazilian freshwater mussels}

The first studies on South American Unionida fauna occurred during the time of great expeditions; several naturalists/collectors came to or received material from South America. One of the byproducts of this activity was that most part of South American type specimens are currently keep in European museums. Ironically, few species of naiads were described by South American researches, some exceptions are Bonetto (1962), Bonetto \& Tassara (1987) and Mansur \& Pimpão (2008). In this phase, the descriptions were based mainly on the shells and, the species nowadays recognized as Diplodon or Rhipidodonta, were placed in the genus Unio Retzius, 1788 and commonly any variation of the shell was described as a new species, resulting in a large number of species names.

To this descriptive phase, a new phase in the study of South American freshwater mussels followed, that encompassed the organization and analysis of these names, with the aim to determine what really correspond to a biological species. Ihering (1893), a Deutsch zoologist established in Brazil, made the first attempt to organize some Brazilian species, and an improved work was published later (Ihering, 1910). He also published a series of studies about Brazilian mussels (e.g., Ihering, 1890, 1891), including some specimens from little studied states of Brazil, like Goiás (Ihering, 1904). Morretes (1949) is the first catalogue about freshwater mussels of Brazil made by a Brazilian researcher. Marshall (1917, 1922, 1923, 1926, 1927) described a series of South American species and proposed two new genera, Diplodontites Marshall, 1922 and Mycetopodella, both still in use (Simone 2006, Graf \& Cummings 2007). Ortmann received a large amount of specimens from South America with soft parts that allowed him to describe new species and produced the above mentioned catalogue (Ortmann, 1921). Haas (1930, 1931a,b) published a catalog about South American species in a series of fully illustrated works. Haas (1969) is a landmark in the study of freshwater bivalves not only in South America but also in the world, and remains as the most "modern" global catalog of Unionida species with synonymic lists. At the same time Cox et al. (1969) presents a scheme including fossil groups.

The formation of South American freshwater mussel researches finally starts in the 1950's. Argentino A. Bonetto from the 1950's onwards published a series of papers concerning the mussel fauna of South America. From his extensive bibliography we can mention some of his studies about Rhipidodontini: dealing with diversity and anatomy (Bonetto 1954, 1962, 1964, 1965, 1967, Bonetto \& Mansur 1970), larval stages (Bonetto 1961, 1965, Bonetto \& Ezcurra 1965), museum collection revision (Bonetto 1973) and factors that affect mussel distribution (Bonetto et al. 1962, Bonetto \& Di Persia 1975). The author also described two new species of Diplodon (Bonetto 1962, Bonetto \& Tassara 1987) and one subgenus (Bonetto et al. 1986).

Amongst the most important papers published by Juan J. Parodiz about mussels are the compendium of available names for Diplodon (Parodiz 1968) and a study about the hybridization of Diplodon delodontus (Parodiz 1973). However, his masterpiece was the catalog about continental fossil molluscs (Parodiz 1969). Parodiz \& Bonetto (1963) suggested a systematic arrangement of Unionida families based on larval type (see details above).

In Brazil, the studies of freshwater mussels intensified during the 1960's. Zanardini (1965) published a note about the occurrence and distribution of Diplodon and Anodontites Bruguière, 1792 in the state of Paraná. A greater increase in knowledge about freshwater mussel fauna began with the works of Mansur (1970) that presented the catalog of Hyriidae and Mycetopodidae of the state of Rio Grande do Sul. She published works dealing with specimens from southern Brazil (Mansur 1972, 1973, Mansur \& Anflor 1982, Mansur \& Pereira 2006) as well as from the Amazon River basin (Mansur \& Valer 1992, Mansur \& Pimpão 2008, Pimpão \& Mansur 2009) and Pantanal (Serrano et al. 1998, Callil \& Mansur $2005,2007)$. There are also two technical works, one identifying Southern and Southeastern genera of mussels (Mansur et al. 1987) and another on how to obtain and identify glochidia (Mansur \& Campos-Velho 1991). Recently, her studies are mainly concerned with non-native bivalves (Mansur et al. 2012). The morphological aspects of Mycetopodidae were also studied in southern South America (Veitenheimer-Mendes 1973a,b, Veintenheimer-Mendes \& Mansur 1978a,b, 1979).

Other researchers also studied freshwater mussels in Brazil. At the state of Rio de Janeiro, L.C. Alvarenga and C.N. Ricci studied the soft parts and glochidium of Diplodon multistriatus (Ricci et al. 1988, 1990), as well as the morphology of soft parts, glochidium and shell variation of Diplodon besckeanus (Alvarenga \& Ricci 1977a,b, 1981). In the field of functional anatomy, there are the works of Wagner Avelar (Avelar \& Santos 1992, Avelar 1993, Avelar \& Cunha 2009) and Nilton Hebling (Hebling \& Penteado 1974, Hebling 1976) concerning Hyriidae and Mycetopodidae species. Simone $(1994,1997)$ described the morphology of two species of Anodontites. Simone (2006) published an illustrated catalogue of molluscs species of Brazil (details above).

There are few studies on ecology, population dynamics and reproduction in Brazil. As the taxonomic and systematic issues have not been properly handled for most species, this often becomes an obstacle for ecological approaches. Henry \& Simão (1985) analyzed the distribution of a population of Diplodon delodontus expansus (Küster, 1856) in the state of São Paulo. Beasley (2001) presents strategies for managing hyriids from the Amazon River basin. Meyer et al. (2010) evaluated the population structure and sexual proportion in a population of Diplodon expansus. Beasley et al. (2005) presented the reproductive cycle of Paxyodon syrmatophorus (Meuschen, 1781), while Avelar \& Mendonça (1998) presented the gametogenesis of Diplodon rotundus gratus. Tomazelli et al. (2003) suggested the potential use of $A$. trapesialis as biological sentinel and the life cycle of this species were investigated by Callil \& Mansur (2007) and Callil et al (2012). Lopes et al. (2011) identified the parasite interaction in Diplodon suavidicus parasited by Hysterothylacium sp. (Nematoda). Recently the first phylogenetic approach of Hyriidae in Brazil was presented by Santos-Neto et al. (2016).

Important faunal surveys about freshwater mussels exist in other South American countries: French Guyana (Drouet 1859, Massemin et al. 2010), Suriname (Verhout 1914), Venezuela (Baker 1930, Lasso et al. 2009, Cummings \& Mayer 2011), Peru (Ramírez et al. 2003), Paraguay (Quintana 1982), Argentina (Rumi et al. 2008), Uruguay (Corsi 1901, Olazarri 1966, Scarabino \& Mansur 2007, Clavijo 2009) and Chile (Parada \& Peredo 2002).

\section{Conclusions}

The large number of works concerning freshwater mussels in South America can give a false idea that the knowledge about these species is deep, but most of works are discreet and deal with one or two species. Comparative approaches of all kinds (morphological, ecological or molecular) are virtually absent. Even basic information is missing, as many species have not been studied beyond the original description. There have been some recent advances in Unionida systematic and the scheme with six or five families looks well established. However, the relationships inside the groups (e.g., families, genera) are poorly known and Rhipidodontini is not an exception. More data were needed to a better comprehension of the species and try to definitively solve questions like the status of Rhipidodonta. It is also an important step in order to reveal the real diversity of this group. The absence of good taxonomic and systematic information has been a limiting factor for biological and ecological studies, preventing appropriated extinction risk evaluation. The interactions of native with the invasive species need to be better understood, considering that the dispersion of the latter is notorious and harmful for native species. Integrating all this information is essential to development of appropriate conservation strategies for freshwater mussels in South America. 


\section{Supplementary material}

The following online material is available for this article:

Appendix I - Taxonomical arrangement of principal revisions of Rhipidodontini. E - species; SE - subspecies; NA - not used by the author as species or subspecies.

\section{Acknowledgments}

Our gratitude goes to CNPq/PROTAX (562291/2010-5) for financial support to SBS and scholarship to ICM; to the curators of MNRJ, MHNM, ZMB, SMF and LDM for the support during the museum surveys; to the two anonymous reviewers that contributed to improve the manuscript.

\section{Author contribution}

Igor Christo Miyahira: conception and design, data acquisition, data analysis, text editing, critical revision

Maria Cristina Dreher Mansur: conception and design, data analysis, text editing, critical revision

Sonia Barbosa dos Santos: conception and design, data analysis, text editing, critical revision

\section{Conflicts of interest}

The authors declare to have no conflict of interest.

\section{References}

ALVARENGA, L.C.F. \& RICCI, C. 1977a. Contribuição ao conhecimento dos gloquídios do gênero Diplodon Spix, 1827: D. besckeanus (Dunker, 1849) (Bivalvia: Unionoidea: Hyriidae). Anais do V Encontro de Malacologistas Brasileiros 33-38.

ALVARENGA, L.C.F. \& RICCI, C. 1977b. Variações morfológicas encontradas nas conchas de uma população de Diplodon besckeanus (Dunker, 1849) (Bivalvia: Unionoidea: Hyriidae). Anais do V Encontro de Malacologistas Brasileiros 41-53.

ALVARENGA, L.C.F. \& RICCI, C. 1981. Morfologia das partes moles de Diplodon (D.) besckeanus (Dunker, 1849) (Bivalvia, Unionoidea, Hyriidae). Bol. Mus. Nac., Zool. 298: 1-8.

AMARAL, A.C.Z., RIBEIRO, C.V., MANSUR, M.C.D., SANTOS, S.B., AVELAR, W.E.P., MATTHEWS-CASCON, H., LEITE, F.P.P., MELO, G.A.S., COELHO, P.A., BUCKUP, G.B., BUCKUP, L., VENTURA, C.R.R. \& TIAGO, C.G. 2008 A situação de ameaça dos invertebrados aquáticos no Brasil. In Livro vermelho da fauna brasileira ameaçada de extinção (Machado, A.B.M., Drummond, G.M. \& Paglia, A.P., orgs). Ministério do Meio Ambiente, Brasilia, p. 156-301.

ARTEAGA-SOGAMOSO, E. 1994. El lasidium de Acostaea rivoli Deshayes, 1827 (Mollusca; Bivalvia-Etheriidae) y su importancia para la ubicación taxonômica de esta espécie. Bol. ecotropica 27: 1-9.

AVELAR, W.E.P. 1993. Funcional anatomy of Fossula fossiculifera (D'Orbigny 1843) Bivalvia Mycetopodidae. Am. Malacol. Bull. 10: 129-138.

AVELAR, W.E.P. \& SANTOS, S.C.D. 1992. Functional morfology of Castalia undosa undosa (Martens, 1827) Bivalvia Hyriidae. Velinger 34: 21-31.

AVELAR, W.E.P. \& MENDONÇA, S.H.S. 1998. Aspects of gametogenesis of Diplodon rotundus gratus (Wagner,1827) (Bivalvia Hyriidae). Am. Malacol. Bull. 14(2): 157-165.

AVELAR, W.E.P. \& CUNHA, A.D. 2009. The anatomy and functional morphology of Diplodon rhombeus fontainianus (Orbigny, 1835) (Mollusca, Bivalvia, Hyriidae). Braz. J. Biol. 69(4):1153-1163.

BAKER, H.B. 1930. The Mollusca collected by the University of Michigan Williamson Expedition in Venezuela. Part VI. Occas. pap. Mus. Zool. Univ. Mich. 9(210): 1-95.

BEASLEY, C.R. 2001. The impact of explotation on freshwater mussels (Bivalvia: Hyriidae) in the Tocantins river, Brazil. Stud. Neotrop. Fauna 36(2): 159-165.

BEASLEY, C.R., MIRANDA, L.Q., ALVES, S.T.M., MELO, A.G., SOUZA, J.O. \& TAGLIARO, C.H. 2005. Brood size and larval length of Paxyodon syrmatophorus (Bivalvia, Hyriidae) from the Tocantins river, Brazil. Amazoniana 18(3/4): 173-184.

BIELER, R. \& MIKKELSEN, A.P.M. 2006. Bivalvia - a look at the branches. Zool. J. Linnean Soc. 148: 223-235.

BIELER, R., CARTER, J.G. COAN, E.V. 2010. Classification of bivalve families. Malacologia 52(2): 113-184.

BIELER, R., MIKKELSEN, P.M.; COLLINS, T.M., GLOVER, E.A., GONZÁLEZ, V.L., GRAF, D.L., HARPER, E.M., HEALY, J., KAWAUCHI, G.Y., SHARMA, P.P., STAUBACH, S., STRONG, E.E., TAYLOR, J.D., TËMKIN, I., ZARDUS, J.D., CLARK, S., GUZMÁN, A., MCINTYRE, E., SHARP, P. \& GIRIBET, G. 2014. Investigating the Bivalve Tree of Life - an exemplar-based approach combining molecular and novel morphological characters. Invertebrate Systematics 28: 32-115.

BOGAN, A.E. 2008. Global diversity of freshwater mussels (Mollusca, Bivalvia) in freshwater. Hydrobiologia 595: 139-147.

BOGAN, A.E. \& HOEH, W.R. 2000. On becoming cemented: evolutionary relationships among the genera in the freshwater familiy Etheriidae (Bivalvia: Unionoida). In The evolutionary biology of the Bivalvia (Harper, E.M.; Taylor, J.D. \& Crame, J., eds). Geological Society, London, London, p.159-168.

BOGAN, A.E. \& ROE, K.J. 2008. Freshwater bivalve (Unioniformes) diversity, systematics, and evolution: status and future directions. J. North Am. Benthol. Soc. 27(2):349-369.

BOLTOVSKOY, D. \& CORREA, N. 2015. Ecosystem impacts of the invasive bivalve Limnoperna fortunei (golden mussel) in South America. Hydrobiologia 746: 81-95.

BONETTO, A.A. 1954. Nayades del rio Parana - el genero Diplodon en el biotope isleño del Parana medio e inferior. Secretaria de Agricultura, Ganaderia e Industrias - Publicación Tecnica, Santa Fé.

BONETTO, A.A. 1961. Investigaciones acerca de las formas larvales en el genero "Diplodon" y su aplicacion a los studios sistematicos. Direccion General de Recursos Naturales - Publicación Técnica, Santa Fé.

BONETTO, A.A. 1962. Notas sobre Diplodon charruanus (Orb.) y Diplodon rhuacoicus (Orb.). Direccion General de Recursos Naturales - Publicación Técnica, Santa Fé.

BONETTO, A.A. 1964. Las species del Género Diplodon (Moll. Unionacea) en los ríos de la pendiente Atlántica del sur del Brasil. Physis 24(68): 323-328.

BONETTO, A.A. 1965. Las especies del genero Diplodon en el sistema hidrografico del rio de La Plata. In Anais do II Congresso Latino-Americano de Zoologia (Guimarães, L.R. coord.) Departamento de Zoologia da Secretária de Agricultura, São Paulo, p.37-54.

BONETTO, A.A. 1967. La superfamilia Unionacea en la Cuenca Amazonica. In Atas do Simpósio sôbre a Biota Amazônica - Limnologia (Lent, H., ed.) Conselho Nacional de Pesquisas, Rio de Janeiro, p. 63-82.

BONETTO, A.A. 1973. Estudio revisivo de las colecciones de nayades de d'Orbigny existentes en el Museo Britanico. Sociedad Cientifica Argentina sección Santa Fé 1: 17-25.

BONETTO, A.A. 1997. Las "ostras de agua dulce" (Muteloidea: Mutelidae). Su taxonomía y distribución geográfica en el conjunto de las naiades del mundo. Biociências 5(1): 113-142.

BONETTO, A.A., MACIEL, I. \& PIGNALBERI, C. 1962. Algunos factores ecologicos vinculados a la distribucion geografica de las nayades en el rio Parana y sus afluentes. Direccion General de Recursos Naturales- Publicación Técnica, Santa Fé, p.167-175.

BONETTO, A.A. \& EZCURRA, I. 1965. Estudio comparado de las formas larvales de Mutelidae Ortmann y su significacion sistematica y zoogeografica. In Anais do II Congresso Latino-Americano de Zoologia (Guimarães, L.R. coord.) Departamento de Zoologia da Secretária de Agricultura, São Paulo, p. 55-71.

BONETTO, A.A. \& MANSUR, M.C.D. 1970. Las nayades de la Cuenca del Guaiba. Acta Zool. Lilloana 27: 241-260.

BONETTO, A.A. \& DI PERSIA, D.H. 1975. Las poblaciones de pelecipodos del arroyo Ayui Grande (prov. Entre Rios) y los facores qye regulan sua distribucion y estrutura. Ecosur 2(3): 123-151. 
BONETTO, A.A., TASSARA, M.P. \& RUMI, A. 1986. Australis n. subgen. de Diplodon Spix (Bivalvia, Unionacea) y posibles relaciones con Hyriidae australianos. Bol. Soc. Biol. Concepc. 57: 55-61.

BONETTO, A.A. \& TASSARA, M.P. 1987. Contribucion al conocimento de dos nayades sudamericanas. Rev. Mus. Argent. Cienc. Nat. Bernardino Rivadavia Inst. Nac. Invest. Cienc. Nat - Zool. 24(11): 163-170.

CALLIL, C.T. \& MANSUR, M.C.D. 2005. Ultrastructural analysis of the shells of Anodontites trapesialis (Lamarck) and Anodontites elongatus (Swaison) (Mollusca, Bivalvia, Etherioidea) from the Mato Grosso Pantanal Region, Brazil. Rev. Bras. Zool. 22(3): 724-734.

CALLIL, C.T. \& MANSUR, M.C.D. 2007. Gametogênese e dinâmica da reprodução de Anodontites trapesialis (Lamarck) (Unionoida, Mycetopodidae) no lago Baía do Poço, planície de inundação do rio Cuiabá, Mato Grosso, Brasil. Rev. Bras. Zool. 24: 825-840.

CALLIL, C.T., KRINSKI, D. \& SILVA, F.A. 2012. Variations of the larval incubation of Anodontites trapesialis (Unionoida, Mycetopodidae): Synergetic effect of the environmental factors and host availability. Braz. J. Biol. 72(3): 545-552.

CAMPBELL, J.D., COOMBS, D.S. \& GREBNEFF, A. 2003. Willsher group and geology of the Triassic Kaka Point coastal section, south-east Otago, New Zeland. J. R. Soc. N. Z. 33: 7-38.

CLAVIJO, C. 2009. Distribución del género Anodontites (Mollusca: Bivalvia: Mycetopodidae) en Uruguay. Comun. Soc. Malacol. Urug. 9(92): 201-210.

CLAVIJO, C. 2017. The Pearl industry and pioneering research in biology and conservation of pearl mussels (Unionoida) in the Río de La Plata Basin. Tentacle 25: 14-15.

CORSI, A.F. 1901. Molluscos de la Rupublica Oriental del Uruguay. Anales Mus. Nac. Montevideo 2: 295-499.

COX, L.R., NEWELL, N.D., BOYD, D.W., BRANSON, C.C., CASEY, R., CHAVAN, A., COOGAN, A.H., DECHASEAUX, C., FLEMING, C.A., HAAS, F., HERTLEIN, L.G., KAUFFMAN, E.G., KEEN, A.M., LAROCQUE, A., MCALESTER, A.L., MOORE, R.C., NUTTALL, C.P., PERKINS, B.F., PURI, H.S., SMITH, L.A., SOOT-RYEN, T., STENZEL, H.B., TRUEMAN, E.R., TURNER, R.D. \& WEIR, J. 1969. Treatise on Invertebrate Paleontology - Part N, Volume 1 (of 3), Mollusca 6, Bivalvia. The Geological Society of America, Inc. and The University of Kansas. Kansas.

CUMMINGS, K.C. \& MAYER, C.A. 2011. The Freshwater Mussels (Bivalvia: Etherioidea) of Venezuela. http:/www.inhs.uiuc.edu/animals plants/mollusk/ SA/Ven.html. (last acess in February/2017).

DARRIGRAN, G. \& DAMBORENEA, C. 2006. Bio-invasión del mejillón dorado en el continente americano. Editorial de la Universidad de La Plata. La Plata, La Plata.

DARRIGRAN, G., DAMBORENEA, C. \& GRECO, N. 2007. Freshwater invasive bivalves in man-made environments: A case study of larvae biology of Limnoperna fortunei in a Hydroelectric Power Plant in South America. AMBIO, 36(7):575-579

DROUET, H. 1859. Essai sur les mollusques terrestres et fluviátiles de la Guyane Française. JB Baillière, Libraire de L'Académie de Médecine, Paris.

FRANC, 1960. Classe des Bivalves. In: Traité de Zoologie - Tome V, Fascicule II (Grassé, P.P., Ed.) Masson et cie Éditeurs, Paris. p.1855-2164p.

GIRIBET, G. 2008. Bivalvia. In Phylogeny and evolution of the Mollusca (Ponder, W.F. \& Lindberg, D.R., eds). University of Carolina Press, Berkeley, p.105-141.

GRAF, D.L. 2000. The Etherioidea revisited: a phylogenetic analysis of Hyriid relationships (Mollusca: Bivalvia: Paleoheterodonta: Unionoida). Occas. pap. Mus. Zool. Univ. Mich. 729: 1-21.

GRAF, D.L. \& CUMMINGS, K.S. 2006. Paleoheterodont diversity (Mollusca: Trigonoida + Unionoida): what we know and what we wish we knew about freshwater mussel evolution. Zool. J. Linnean Soc. 148: 343-394.

GRAF, D.L. \& CUMMINGS, K.S. 2007. Review of the systematic and global diversity of freshwater mussel species (Bivalvia: Unionoida). J. Mollus. Stud. 73: 291-314.

GRAF, D.L., JONES, H., GENEVA, A.J.; PFEIFER III, J.M. \& KLUNZINGER, M.W. 2015. Molecular phylogenetics analysis supports a Gondwanan origin of the Hyriidae (Mollusca: Bivalvia: Unionoida) and the paraphyly of Australasian taxa. Mol. Phylogenet. Evol. 85: 1-9.
HAAG, W.R. 2012. North American freshwater mussels: natural history, ecology and conservation. Cambridge University Press, Cambridge.

HAAS, F. 1916. Nayades del viaje al Pacifico. Trabajos Mus. Nacion. Cienc. Nat., Madrid, (Zool.) 25:1-63.

HAAS, F. 1929. Beitrag zur Kenntnis der südamerikanischen Binnenmollusken. Senckenbergiana Biol. 11(:8-13.

HAAS, F. 1930. Versuch einer kritischen Sichtung der sudamerikanischen Najaden, hauptsachlich an Hand der Sammlung des Senckenberg-Museums I. Senckenbergiana, 12: 175-195.

HAAS, F. 1931a. Versuch einer kritischen Sichtung der sudamerikanischen Najaden, hauptsachlich an Hand der Sammlung des Senckenberg-Museums II. Senckenbergiana, 13: 30-52.

HAAS, F. 1931b. Versuch einer kritischen Sichtung der sudamerikanischen Najaden, hauptsachlich an Hand der Sammlung des Senckenberg-Museums III. Senckenbergiana, 13: 87-110.

HAAS, F. 1938. Neue Binnen-Mollusken aus Nordost-Brasilien. Arch. Moll. 70: 46-51.

HAAS, F. 1966. On some new non-marine mollusks from Colombia and Peru. Fieldiana Zool. 44(25):231-240.

HAAS, F. 1969. Superfamilia Unionacea. In Das Tierrich, Lieferung - vol 88 (Martens, R., Hennig W. \& Wermuth, H., ed.). Walter de Gruyter and Co., Berlin.

HEBLING, N.J. 1976. The functional morphology of Anodontites trapezeus (Spix) and Anodontites trapesialis (Lamarck) (Bivalvia: Mycetopodidae). Bol. Zool. Univ. São Paulo 1: 265-298.

HEBLING, N.J. \& PENTEADO, A.M.G. 1974. Anatomia functional de Diplodon rotundus gratus Wagner, 1827 (Mollusca, Bivalvia). Rev. Bras. Biol. 34(1): 67-80.

HENRY, R. \& SIMÃO, C.A. 1985. Spatial distribution of a bivalve population (Diplodon delodontus expansus) (Küster, 1856) in a small tropical reservoir. Rev. Bras. Biol. 45(4): 407-415.

HOEH, W.R. \& BOGAN, A.E. 2000. On becoming cemented: evolutionary relationships among the genera in freshwater bivalve family Etheriidae (Bivalvia: Unionoida). In: Harper, E.M., Taylor, J.D. Cramer, J.A. (eds) The evolutionary biology of the Bivalvia. Geological Society, London. p. 159-168.

HOEH, W.R., BOGAN, A.E. \& HEARD, W.H. 2001. A phylogenetic perspective on the evolution of morphological and reproductive characteristics in the Unionoida. In: Bauer, G. \& Wächtler, K. (eds.) Evolution of the freshwater mussels Unionoida. Springer-Verlag, Berlin.

HOEH, W.R., BOGAN, A.E., HEARD, W.H. \& CHAPMAN, E.G., 2009. Paleoheterodont phylogeny, character evolution, diversity and phylogenetic classification: a reflection of method of analysis. Malacologia 51: 307-317.

IHERING, H. 1890. Revision der von Spix in Brasilien gesammelten najaden. Arch. Naturgesch. 56(1): 117-170.

IHERING, H. 1891. Anodonta und Glabaris. Zool. Anz. 14: 474-484.

IHERING, H. 1893. Najaden von S. Paulo und die geographische verbreitung der süsswasserfauna von Südamerika. Arch. Naturgesch. 59: 45-140.

IHERING, H. 1904. Zur kenntnis der najaden von Goyaz. Nachr.bl. Dtsch. Malakozool. Ges. 36(4): 154-157.

IHERING, H. 1910. Über brasilianische najaden. Abh. Senckenb. Naturforsch. Ges. 32: 111-140.

KABAT, A.R. 1997. Correct family names for the freshwater "Muteloid" bivalves (Unionoida: Etherioidea). Occas. pap. mollusks 5(72): 379-392.

LASSO, C.A., MARTÍNEZ-ESCARBASSIERE, R., CAPELO, J.C., MORALESBETANCOURT, M.A. \& SÁNCHEZ-MAYA, A. 2009. Lista de los moluscos (Gastropoda-Bivalvia) dulceacuícolas y estuarinos de la cuenca del Orinoco (Venezuela). Biot. Colombiana 10(1/2): 63-74.

LEA, I. 1836. A synopsis of the family of naiades. Cary, Lea and Blanchard, Philadelphia.

LOPES, L.P., PIMPÃO, D.M., TAKEMOTO, R.M., MALTA, J.C. \& VARELLA, A.M. 2011. Hysterothylacium larvae (Nematoda, Anisakidae) in the freshwater mussel Diplodon suavidicus (Lea, 1856) (Mollusca, Unioniformes, Hyriidae) in Aripuanã River, Amazon, Brazil. J. Invertebr. Pathol. 106(3): 357-359.

MANSUR, M.C.D. 1970. Lista dos moluscos bivalves das famílias Hyriidae e Mycetopodidae para o estado do Rio Grande do Sul. Iheringia Ser. Zool. 39:33-95. 
MANSUR, M.C.D. 1972. Morfologia do sistema digestivo de Castalia undosa martensi (Ihering, 1891) (Bivalvia: Hyriidae). Iheringia Ser. Zool.41: 21-34.

MANSUR, M.C.D. 1973. Morfologia do sistema digestivo das especies do gênero Diplodon Spix, 1827 do rio Guaíba, Rio Grande do Sul (Unionacea - Hyriidae) Iheringia Ser. Zool.43: 75-90.

MANSUR, M.C.D. 1999. Gloquídio de Diplodon martensi (Ihering) (Mollusca, Bivalvia, Hyriidae) e seu ciclo parasitário. Rev. Bras. Zool. 16(Supl. 2): 185-194.

MANSUR, M.C.D. 2007. Moluscos da classe Bivalvia que tiveram sucesso ao se irradiarem no ambiente de água doce. 27-29p. In: Livro de Resumos do XX Encontro Brasileiro de Malacologia, Rio de Janeiro. 406pp.

MANSUR, M.C.D. \& ANFLOR, L.M. 1982. Diferenças morfológicas entre Diplodon charruanus (Orbigny, 1835) e D. pilsbry Marshall, 1928 (Bivalvia: Hyriidae). Iheringia Ser. Zool.60: 101-106.

MANSUR, M.C.D., SCHULZ, C. \& GARCES, L.M.M.P. 1987. Moluscos bivalves de água doce: identificação dos gêneros do sul e leste do Brasil. Acta Biol. Leopold. 9(2): 181-202.

MANSUR, M.C.D. \& CAMPOS-VELHO, N.M.R. 1990. Técnicas para o estudo dos gloquídios de Hyriidae (Mollusca, Bivalvia, Unionoida). Acta Biol. Leopold. 12(1): 5-18.

MANSUR, M.C.D. \& VALER, R.M. 1992. Moluscos bivalves do Rio Uraricoera e Rio Branco, Roraima, Brasil. Amazoniana 12(1): 85-100.

MANSUR, M.C.D. \& SILVA, M.G.O. 1999. Description of glochidia of five species of freshwater mussels (Hyriidae: Unionoidea) from South America. Malacologia 41(2): 475-483

MANSUR, M.C.D., QUEVEDO, C.B., SANTOS, C.P. \& CALLIL, C.T. 2004a Provavéis vias de introdução de Limnoperna fortunei (Dunker, 1857) (Mollusca, Bivalvia, Mytilidae) na bacia da Laguna dos Patos, Rio Grande do Sul e novos registros de invasão no Brasil pelas bacias do Paraná e Paraguai. In Água de lastro e bioinvasão (Silva, J.S.V. \& Souza, R.C.C.L, orgs) Editora Interciência, Rio de Janeiro, p. 33-38.

MANSUR, M.C.D., CALLIL, C.T., CARDOSO, F.R. \& IBARRA, J.A.A. 2004b Uma retrospectiva e mapeamento da invasão de espécies de Corbicula (Mollusca, Bivalvia, Veneroida, Corbiculidae) oriundas do sudeste Asiático, na América do Sul. In Água de lastro e bioinvasão (Silva, J.S.V. \& Souza, R.C.C.L, orgs) Editora Interciência, Rio de Janeiro, p.39-58.

MANSUR, M.C.D. \& PEREIRA, D. 2006. Bivalves límnicos da bacia do rio dos Sinos, Rio Grande do Sul, Brasil (Bivalvia, Unionoida, Veneroida e Mytiloida). Rev. Bras. Zool. 23(4): 1123-1147.

MANSUR, M.C.D. \& PIMPÃO, D.M. 2008. Triplodon chodo, a new species of species of pearly fresh water mussel from Amazon Basin (Mollusca: Bivalvia: Unionoida: Hyriidae). Rev. Bras. Zool. 25(1): 111-115.

MANSUR, M.C.D., SANTOS, C.P., PEREIRA, D., PAZ, I.C.P., ZURITA, M.L.L., RODRIGUEZ, M.T.R., NEHRKE, M.V. \& BERGONCI, P.E.A. 2012. Moluscos límnicos invasores no Brasil: biologia, prevenção e controle. Redes Editora, Porto Alegre.

MARSHALL, W.B. 1917. New and little now species of South American freshwater mussels of the genus Diplodon. Proc. U. S. Nat. Mus. 53(2209): 381-388.

MARSHALL, W.B. 1922. New pearly freshwater mussels from South America. Proc. U. S. Nat. Mus. 61(16): 1-9.

MARSHALL, W.B. 1923. New pearly freshwater mussels from Mexico and Uruguay. Proc. U. S. Nat. Mus. 63(16): 1-4

MARSHALL, W.B. 1926. New land and freshwater mollusks from South America. Proc. U. S. Nat. Mus. 69(12): 1-12.

MARSHALL, W.B. 1927. A new genus and two new species of South American fresh-water mussels. Proc. U. S. Nat. Mus. 71(2): 1-4.

MASSEMIN, D., LAMY, D., POINTIER, J.P. \& GARGOMINY, O. 2010. Coquillages et Escargots de Guyane. 456 pp.

MATOS, E. 2007. Ação parasitária em cultivo de moluscos bivalves: um estudo de casa no Nordeste do estado do Pará. In Tópicos em Malacologia - Ecos do XVIII Encontro Brasileiro de Malacologia (Santos, S.B., Pimenta, A.D., Thiengo, S.C., Fernandez, M.A. \& Absalão, R.S., orgs.). Technical Books, Rio de Janeiro, p.209-216.
MEYER, A.A.N., OLIVEIRA, E. \& MARTIM, J. 2010. Classes de comprimento e proporção sexual em Diplodon expansus (Mollusca, Bivalvia, Hyriidae) no rio Piraquara, Paraná, Brasil. Iheringia Ser. Zool. 100(4): 329-335.

MEYER, A.A.N., MARTIN, J.K. \& OLIVEIRA, E. 2013. Ocorrência e caracterização histológica de marsúpios de Diplodon expansus (Küster, 1856) (Mollusca, Bivalve, Hyriidae) no rio Piraquara, Paraná, Brasil. Biotemas 26(1): 97-108.

MEYER, A.A.N., OLIVEIRA, E., TEIXEIRA, T.B. \& VIESSER, J.A. 2014. Classes de comprimento e descrição histológica das gônadas de Diplodon ellipticus (Wagner, 1827) (Mollusca, Bivalvia, Hyriidae) em um lago artificial, Morretes, Paraná, Brasil. Biotemas 27(3): 81-96.

MIYAHIRA, I.C., SANTOS, S.B., MANSUR, M.C.D. \& CARNEIRO, J.B. 2012 Freshwater mussels in Brazil: past, present and future, at least, we hope they have one. American Conchologist 40: 16-18.

MIYAHIRA, I.C., MANSUR, M.C.D. \& SANTOS, S.B. 2013. Revision of the type specimens of Diplodon ellipticus and Diplodon expansus. Spixiana 36: 173-182.

MIYAHIRA, I.C., CARNEIRO, J.B., GONCALVES, I.C.B., LACERDA, L.E.M. OLIVEIRA, J.L., VASCONCELLOS, M.C. \& SANTOS, S.B. 2017. Freshwater mollusks and environmental assessment of Guandu River, Rio de Janeiro, Brazil. Biota Neotropica 17(3): http://dx.doi.org/10.1590/1676-0611-BN-2017-0342.

MODELL, H. 1942. Das natürliche system der najaden. Archiv für Molluskenkunde 74(5/6): 161-191. (in German, English translation in Stansberry, D.H. \& Soehngen, U. 1964. Sterkiana 14: 1-18).

MORRETES, F.L. 1949. Ensaio do catálogo dos moluscos do Brasil. Arq. mus. Paranaense 7: 5-216.

NEVES, R.J. 1999. Conservation and commerce: management of freshwater mussel (Bivalvia: Unionoidea) resources in the United States. Malacologia 41(2): 461-474

NEVESSKAJA, L.A. 2009. Principle of systematics and the system of Bivalves. Paleontol. J. 43(1): 1-11

NEWELL, N.D. 1965. The classification of the Bivalvia. Am. Mus. Novit .2206: 1-25.

OLAZARRI, J. 1966. Los moluscos de Agua Dulce Del Depto. de Colonia, Uruguay. Part I: Pelecypoda. Comun. Soc. Malacol. Urug. 2(11): 15-37.

ORTMANN, A.E. 1911. The anatomical structure of certain exotic naiades compared with that of the North American forms. Nautilus 24: 103-131.

ORTMANN, A.E. 1921. South American naiades, a contribution to the knowledge of the fresh-water mussels of South America. Mem. Carnegie Mus. 8(3): 451-670

PARADA, E. \& PEREDO, S. 2002. Estado actual de la taxonomía de bivalvos dulceacuícolas chilenos: progresos y conflictos. Rev. Chil. Hist. Nat. 75: 691-701.

PARODIZ, J.J. 1968. Annotated catalogue of the genus Diplodon (Unionacea Hyriidae). Sterkiana 30: 1-22.

PARODIZ, J.J. 1969. The tertiary non-marine Mollusca of South America. Ann. Carnegie Mus. 40: 1-242.

PARODIZ, J.J. 1973. The species complex of Diplodon delodontus (Lamarck) (Unionacea - Hyriidae). Malacologia 14: 247-270.

PARODIZ, J.J. \& BONETTO, A.A. 1963. Taxonomy and Zoogeography relationships of the South American naiads (Pelecypoda: Unionacea and Mutelacea). Malacologia 1: 179-213

PEREA, D., SOTO, M., VEROSLAVSKY, G., MARÍNEZ, S. \& UBILA, M. 2009. A Late Jurassic fóssil assemblage in Gondwana: biostratigraphy and correlations of the Tacuarembó Formation, Parana Basin, Uruguay. J. S. Am. Earth Sci. 28, 168-179

PEREIRA, D., ARRUDA, J.O., MENEGAT, R., PORTO, M.L., SCHWARZBOLD, A. \& HARTZ, S.M. 2011. Guildas tróficas, composição e distribuição de espécies de moluscos límnicos no gradiente fluvial de um riacho subtropical brasileiro. Biotemas 24(1): 21-36.

PEREIRA, D., MANSUR, M.C.D., DUARTE, L.D.S., OLIVEIRA, A.S., PIMPÃO D.M., CALLIL, C.T., ITUARTE, C., PARADA, E., PEREDO, S., DARRIGRAN, G., SCARABINO, F., CLAVIJO, C., LARA, G., MIYAHIRA, I.C., RODRIGUEZ, M.T.R. \& LASSO, C. 2014. Bivalve distribution in hydrographic regions in South America: historical overview and conservation. Hydrobiologia 735(1): 15-44

PFEIFER, N.T.S. \& PITONI, V.L.L. 2003. Análise qualitativa estacional da fauna de moluscos límnicos no Delta do Jacuí, Rio Grande do Sul, Brasil. Biociências 11(2):145-158

PHILIPP, E.E.R. \& ABELE, D. 2009. Masters of longevity: lessons from long-lived bivalves - A mini review. Gerontology: 1-11. 
PIMPÃO, D.M. \& MANSUR, M.C.D. 2009. Chave pictórica para identificação dos bivalves do baixo rio Airupuanã, Amazonas, Brasil (Sphaeriidae, Hyriidae e Mycetopodidae). Biota Neotrop. 9: 1-8.

PIMPÃO, D.M., MANSUR, M.C.D., BERGONCI, P.E.A. \& BEASLEY, C.R. 2012. Comparative morphometry and morphology of glochidial shells of Amazonian Hyriidae (Mollusca: Bivalvia: Unionoida). Am. Malacol. Bull. 30, 73-84.

PONDER, W.F. \& LINDBERG, D.R. 2008. Phylogeny and evolution of the Mollusca. University of California, California. 469p.

QUINTANA, M.G. 1982. Catalogo preliminar de la malacofauna del Paraguay. Rev. Mus. Argent. Cienc. Nat. Bernardino Rivadavia, Zool. 11: 61-158.

RAMÍREZ, R., PAREDES, C. \& ARENAS, J. 2003. Moluscos del Perú. Rev. Biol. Trop. 51(Suppl. 3): 225-284.

RICCI, C.N., COELHO, A.C.S \& ALVARENGA, L.C.F. 1988. Diplodon (D.) multistriatus (Lea, 1831): Concha, partes moles e considerações taxonômicas (Mollusca, Bivalvia, Hyriidae). Bol. Mus. Nac. Zool. 325: 1-19.

RICCI, C.N., ALVARENGA, L.C.F. \& COELHO, A.C.S. 1990. Gloquídios de Diplodon Spix, 1827: D. (D.) multistriatus (Lea, 1831) (Mollusca, Bivalvia, Hyriidae). Bol. Mus. Nac. Zool. 344: 1-10.

RUMI, A., GREGORIC, D.E.G., NÚÑEZ, V. \& DARRIGRAN, G.A. 2008. Malacologia Latinoamericana - Moluscos de agua dulce de Argentina. Rev. Biol. Trop. 56(1): 77-111.

RUPPERT, E.E., FOX, R.S. \& BARNES, R.D. 2008. Zoologia dos Invertebrados - Uma abordagem funcional-evolutiva. Editora Roca. São Paulo.

SANTOS, S.B., PIMENTA, A.D., THIENGO, S.C., THOMÉ, J.W., ABSALÃO, R.S., MANSUR, M.C.D., VIDIGAL, T.H.D., FERNANDEZ, M.A., TOMÁS, A.R.G., MESQUITA, E.F.M., SALGADO, N.C., MATTHEWS-CASCON, H., MARTINS, I.X., ROCHA-BARREIRA, C. \& KAWANO, T. 2009. Mollusca. In Estado da arte e perspectivas para a Zoologia no Brasil (Rocha, R.M. \& Boeger, W.A.P., orgs.) Editora UFPR, Curitiba. p.65-90.

SANTOS, S.B., MIYAHIRA, I.C., SALGADO, N.C., HEYDRICH, I., PENA, M.S., COLLEY, E., FERNANDEZ, M.A., THIENGO, S.C., GOMES, S.R., SILVA, M.J.M., GONÇALVES, I.C.B., LACERDA, L.E.M., TALLARICO, L.F. \& MARTINS, D.S. 2015. Observations on review of the list of endangered continental molluscs of Brazil. Tentacle 23: 26-28.

SANTOS-NETO, G.C., BEASLEY, C.R., SCHNEIDER, H., PIMPÃO, D.M., HOEH, W.R., SIMONE, L.R.L. \& TAGLIARO, C.H. 2016. Genetic relationships among freshwater mussel species from fifteen Amazonian rivers and inferences on the evolution of the Hyriidae (Mollusca: Bivalvia: Unionoida). Mol. Phylogenet. Evol. 100: 148-159.

SCARABINO, F. \& MANSUR, M.C.D. 2007. Lista sistematica de los Bivalvia dulciacuícolas viventes de Uruguay. Comun. Soc. Malacol. Urug. 9(90): 89-99.

SCHNEIDER, J.A. 2001. Bivalve systematics during the 20th century. J. Paleo. 75(6): 1119-1127.

SERRANO, M.A.S., TIETBÖHL, R.S. \& MANSUR, M.C.D. 1998. Sobre a ocorrência de moluscos Bivalvia no pantanal de Mato Grosso, Brasil. Biociências 6(1): 131-144.

SIMONE, L.R.L. 1994. Anatomical characters and systematics of Anodontites trapesialis (Lamarck, 1819) from South America (Mollusca, Bivalvia, Unionoida, Muteloidea). Stud. Neotrop. Fauna Environ. 29(3): 169-185.

SIMONE, L.R.L. 1997. Anatomy and systematics of Anodontites elongatus (Swainson) from Amazon and Paraná basins, Brazil (Mollusca, Bivalvia, Unionoida, Mycetopodidae). Rev. Bras. Zool. 14(4): 877-888.

SIMONE, L.R.L. 2006. Land and freshwater molluses of Brazil. EGB, Fapesp, São Paulo. 390pp.
SIMPSON, C.T. 1914. A descriptive catalogue of the Naiades or pearly freshwater mussels. Privately published by Bryant Walker, Michigan.

STRAYER, D.L., DOWINING, J.A., HAAG, W.R., KING, T.L., LAYZER, J.B., NEWTON, T.J. \& NICHOLS, S.J. 2004. Changing perspectives on pearly mussels, North America's most imperiled animals. Bioscience 54(5): 429-439.

THIELE, J. 1934. Handbuch der systematischen Weichtierkunde - part 3 (Scaphopoda/ Bivalvia/Cephalopoda). 779-1022p. (in German, English translation by Bieler, R. \& Mikkelsen, P.M. 1998. Handbook of systematic malacology - part 3 and 4. Smithsonian Institution Libraries, Washington D.C. p. 1193-1690).

TOMAZELLI, A.C., MARTINELLI, L.A., AVELAR, W.E.P., CAMARGO, P.B., FOSTIER, A., FERRAZ, E.S.B., KRUG, F.J. \& JÚNIOR, D.S. 2003. Biomonitoring of $\mathrm{Pb}$ and $\mathrm{Cd}$ in two impacted watersheds in southeast Brazil, using the freshwater mussel Anodontites trapesialis (Lamarck, 1819) (Bivalvia: Mycetopodidae) as a biological monitor. Braz. Arch. Biol. Technol. 46(4): 673-684.

WÄCHTLER, K., MANSUR, M.C.D., RICHTER, T. 2001. Larval type e early postlarval biology in Naiads (Unionoida). In Ecology e Evolution of the Freshwater Mussels Unionoida (Bauer G, Wächtler K., eds.). Springer-Verlag, Berlim. 93-125p.

WHELAN, N.V., GENEVA, A.J. \& GRAF, D.L. 2011. Molecular phylogenetics analysis of tropical freshwater mussels (Mollusca: Bivalvia: Unionoida) resolves the position of Coelatura and supports a monophyletic Unionidae. Mol. Phylogenet. Evol. 61(2): 504-514.

VAUGHN, C.C. 2017. Ecosystem services provided by freshwater mussels. Hydrobiologia. DOI 10.1007/s10750-017-3139-X

VAZ J.F., MANTEGAZZA, E., TELES, H.M.S., LEITE S.P.S. \& MORAIS, L.V.C. 1987. Levantamento planorbídico do Estado de São Paulo (Brasil): 4a Região Administrativa. Rev. Saúde Públ. S. Paulo 21: 371-379.

VEITENHEIMER-MENDES, I.L. 1973a. Contribuição ao estudo do gênero Leila Gray, 1840 (Mycetopodidae: Bivalvia). Iheringia, Ser. Zool. 62(42): 64-89.

VEITENHEIMER-MENDES, I.L. 1973b. Anodontites Bruguière, 1792 no Guaíba - RS (Mycetopodidae: Bivalvia). I - Anodontites trapesialias forbesianus (Lea, 1860). Iheringia, Ser. Zool. 62(44): 32-49.

VEINTENHEIMER-MENDES, I.L. \& MANSUR, M.C.D. 1978a. Mycetopoda legumen: Lasídio e desenvolvimento parasitário (Bivalvia: Mycetopodidae). Rev. Bras. Biol. 38(3): 531-536.

VEINTENHEIMER-MENDES, I.L. \& MANSUR, M.C.D. 1978b. Morfologia, histologia e ecologia de Mycetopoda legumen (Martens, 1888) (Bivalvia: Mycetopodidae). Iheringia, Ser. Zool. 67(52): 33-71.

VEINTENHEIMER-MENDES, I.L. \& MANSUR, M.C.D. 1979. Redescrição de Mycetopoda legumen (Martens, 1888)(Bivalvia: Mycetopodidae). Rev. Bras. Biol. 39(3): 695-702.

VERNHOUT, J.H. 1914. The non-marine molluscs of Surinam. I. Notes Leyden Mus. 36: 1-46.

XU, M., DARRIGRAN, G., WANG, Z., ZHAO, N., LIN, CH \& PAN, B. 2015. Experimental study on control of Limnoperna fortunei biofouling in water transfer tunnels. Journal of Hydro-environment Research 9(2): 248-258.

ZANARDINI, I.F. 1965. Nota sôbre Diplodon e Anodontites (Mollusca-Pelecypoda) de rios de Curitiba (Paraná). Bol. Inst. Def. Patrim. Nat. Zool. 6: 1-11.

Received: 14/03/2017

Revised: 30/08/2017

Accepted: 17/11/2017

Published online: 07/12/2017 